\title{
Tylosaurine mosasaurs (Squamata) from the Late Cretaceous of northern Germany
}

\author{
J.J. Hornung ${ }^{1,2, *} \&$ M. Reich ${ }^{3,4}$
}

1 Georg-August University Göttingen, Geoscience Centre, Department of Geobiology, Goldschmidt-Straße 3, 37077 Göttingen, Germany

2 Current address: Fuhlsbüttler Str. 611, 22337 Hamburg, Germany

3 SNSB - Bavarian State Collection for Palaeontology and Geology, Richard-Wagner-Str. 10, 80333 Munich, Germany

4 Department of Earth and Environmental Sciences, Ludwig-Maximilians University München, Richard-Wagner-Str. 10, 80333 Munich, Germany

* Corresponding author. Email: jhornun@gwdg.de

Manuscript received: 27 April 2014, accepted: 18 September 2014

\section{Abstract}

Two genera of tylosaurine mosasaurs, Tylosaurus and Hainosaurus, are recorded for the first time from Germany. Tylosaurus sp. is represented by two isolated tooth crowns, originally described as Mosasaurus? alseni (here considered a nomen dubium) from the latest Santonian-Early Campanian, which are very similar to T. ivoensis and T. gaudryi. The material of Hainosaurus sp. comprises a maxillary with associated postorbitofrontal, two pterygoid teeth and several indeterminate cranial fragments. The specimen from the Late Campanian is slightly less derived than H. bernardi from the Maastrichtian in retaining labiolingually less compressed anterior maxillary teeth and unserrated pterygoid teeth with only very weak carinae. Despite only minor skeletal differences, the genus Hainosaurus is considered to be distinct from Tylosaurus because of its significant modification of the dental apparatus compared to the plesiomorphic condition in the latter. This dental morphology suggests a phylogenetic trend from a generalised-piercing marginal dentition in Tylosaurus towards the increasingly labiolingually compressed, symmetrical, strongly bicarinate cutting marginal teeth in Hainosaurus spp. from the Early through Late Campanian and Maastrichtian. A similar trend is also present in pterygoid teeth with very indistinct unserrated carinae in the Campanian Hainosaurus sp. towards serrated ones in the Maastrichtian H. bernardi. A short review indicates the presence of Hainosaurus in northern, central and western Europe (Sweden to Spain) since the Early Campanian, and the occurrence of Tylosaurus spp. in the same area until the Late Campanian. Hainosaurus persisted until the end of the Maastrichtian; outside Europe it may have been present in the Late Campanian of the USA and the Maastrichtian of the Democratic Republic of Congo. Judging from a simple, uni- to bicarinate, stoutly conical tooth morphology in aigialosaurs and very basal mosasaurs as well as phylogenetic patterns, the development of blade-like cutting tooth crowns appears to have been convergent in several clades of large-bodied Campanian-Maastrichtian mosasaurids. These include both mosasaurines ('Leiodon' mosasauroides, Prognathodon? sectorius, Prognathodon? kianda, Eremiasaurus heterodontus) and tylosaurines (Hainosaurus spp.).

Keywords: Mosasauridae, Tylosaurinae, Tylosaurus, Hainosaurus, Campanian, evolution

\section{Introduction}

Mosasaurs (Mosasauridae Gervais, 1853) were large, pelagic, predatory squamates with a global distribution during the Late Cretaceous. Among these some of the largest known individuals belong to species of the subfamily Tylosaurinae Williston, 1895, especially the genus Hainosaurus Dollo, 1885a, which attained body lengths of $>15 \mathrm{~m}$ (Lingham-Soliar, 1992). While this subfamily is particularly well represented in the early Late Cretaceous of North America (e.g. Russell, 1967; Everhart, 2005) and reached a near-cosmopolitic distribution during Santonian-Campanian times (e.g. Caldwell et al., 2008), its record from Europe is comparatively rare and much more poorly known. Apart from Hainosaurus bernardi Dollo, 1885a, of which a near-complete skeleton and several crania from the Early Maastrichtian of southern Belgium are known (Dollo, 1885a,b, 1888; Lingham-Soliar, 1992), only scattered finds - mostly of tooth crowns - are widely distributed from the Santonian/Early Campanian through the Late Maastrichtian for localities in southern Sweden (Lindgren, 2005), Belgium (Jagt, 2005), Poland (Jagt et al., 2005), 
England (Jagt et al., 2005), France (Bardet, 1990, 2012) and Spain (Bardet et al., 1997, 2006).

These findings are supplemented by so far misidentified material from the Campanian of northern Germany (Fig. 1). Two tooth crowns, described by Stolley (1892) from the latest Santonian or Early Campanian of Schleswig-Holstein as Mosasaurus? alseni, are restudied and found to share great similarities with Tylosaurus ivoensis (Persson, 1963). They are re-identified as Tylosaurus sp. and represent the first record of this genus from Germany.

Another tylosaurine is represented by a large maxillary with teeth and associated fragments. The specimen was collected in April 1908 from sediments of Campanian age near Haldem (now Stemwede-Haldem), eastern North-Rhine Westphalia. It was firstly described by Pompeckj (1910) and is housed today in the collections of the Geoscience Centre, University of Göttingen (GZG), Lower Saxony. This material constitutes the most comprehensive cranial material known from any mosasaur in Germany (see Sachs et al., 2014, for a historical review, also, for example, Sachs, 2000, 2006; Diedrich \& Mulder, 2004; Caldwell \& Diedrich, 2005; Hornung \& Reich, 2006; Jagt et al., 2006 for more recent records). This particular specimen sparked a detailed discussion on mosasaur palaeobiology and phylogeny by Pompeckj (1910). For a review of its historical significance reference is made to Sachs et al. (2014). Previously, this material was identified as belonging to the genus Mosasaurus Conybeare in Parkinson, 1822 or to Liodon Agassiz, 1846 (= Leiodon 0wen, 1841 in 0wen 1840-45, praeocc.). It is shown below that this specimen can be referred to the genus Hainosaurus, thus constituting the first record of this genus from Germany and the most comprehensive material from Europe outside the type locality of $H$. bernardi in southern Belgium.

Recently, the validity and content of the genus Hainosaurus have been challenged, and it has been proposed that it should be synonymised with Tylosaurus Marsh, 1872 (e.g. see Bullard \&

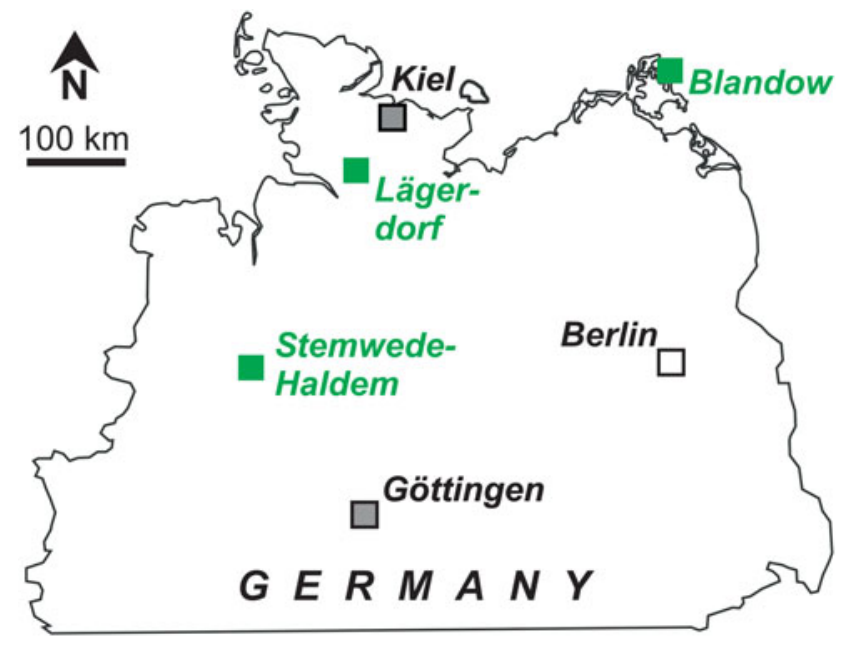

Fig. 1. Map of northern Germany with mosasaur-bearing localities (green) and repositories (grey) mentioned in the text.
Caldwell, 2010). However, for the reasons outlined below, we prefer to retain these genera as distinct.

Earlier, Jagt et al. (2006) indicated that a now lost tooth from the Early Maastrichtian of Blandow (Isle of Rügen, Western Pomerania, northeastern Germany, see Sachs et al. (2014) for a more detailed account) in the former Friedrich von Hagenow collection might be referred to Hainosaurus 'sp. 2' (sensu Jagt et al., 2005). This view was based on the partial reproduction of an unpublished figure of this tooth produced by von Hagenow (Reich \& Frenzel, 2002: pl. 2, fig. 4). However, this figure by von Hagenow in its entirety, here reproduced in Fig. 2, reveals the markedly asymmetric D-shaped cross-section of the lower crown (and apparently of the crown-base) with a strongly convex lingual face and a near-flat labial face. Although the pattern of facets is similar to that of Hainosaurus 'sp. 2 ' there is no indication of any basal tertiary striations that are typical of tylosaurine teeth. However, the teeth of derived species of Mosasaurus show variation in the intensity of faceting, also dependant on the ontogenetic stage (Mulder et al., 2004), and typically also a D-shaped cross-section, especially in rostral marginal teeth (e.g. Lingham-Soliar, 1995; Kuypers et al., 1998; pers. obs.). We therefore here refer to this specimen as Mosasaurus cf. hoffmanni Mantell, 1829, which closely matches the original identification by von Hagenow.

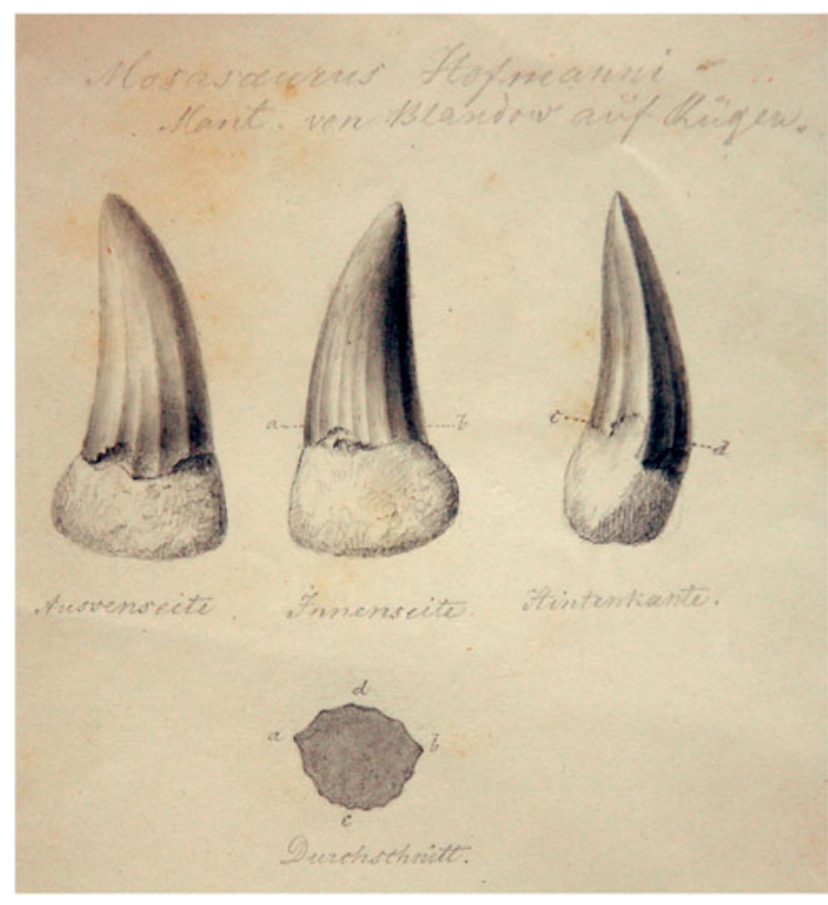

Fig. 2. Unpublished drawing by Friedrich von Hagenow from the 1830s/1840s depicting a mosasaur tooth from the Early Maastrichtian chalk facies of Blandow, Isle of Rügen. Jagt et al. (2006) noted that this specimen (now lost) could possibly represent Hainosaurus 'sp. 2', but it is considered here to be assignable to Mosasaurus cf. hoffmanni Mantell, 1829 on account of its strongly asymmetric cross-section (lower figure). This sketch represents the first record of a mosasaur from Germany (see Sachs et al., 2014). 


\section{Terminology}

The analysis of dental morphology for the identification of mosasaur species has gained increasing importance in recent years (e.g. see Lindgren \& Siverson, 2002, 2004; Lindgren, 2005, for extensive application), although it has also encountered scepticism (e.g. Caldwell \& Diedrich, 2005). Features of the tooth enamel have been described on the basis of varying terms, although their use is not always consistent, sometimes semantically incorrect, or the terminologies adopted are not always unambiguously defined. Here we propose the following definitions for the three-dimensional, apicobasal, linear enamel features which serve to describe the material here considered (Fig. 3).

\section{Circular cross-sections and striations}

Striae (singular stria) are thin, apicobasally striking, linear enamel ridges covering the surface of the tooth crown. On the basis of size and strength, three orders, i.e. primary, secondary and tertiary striae, can commonly be distinguished (Fig. 3a). Secondary striae are less prominent than primary striae and may be intercalated between the former (Fig. 3a/1) or branch off from these (Figs 3a/2 and 3a/4-5). Tertiary striae are much fainter and mostly much denser than primary and secondary ones. Dense tertiary striae are a common feature in teeth of tylosaurines (Lindgren \& Siverson, 2002). In cases where secondary or even primary striae are missing, tertiary striae may nevertheless be present and should be classified as such in order to denote clearly the size difference to the primary striae (Fig. 3a/3). Still finer, short, irregular, not necessarily continuous enamel ridges, often with a patchy distribution across the tooth crown, are wrinkles. Tooth crowns with a continuously curved surface, simply covered in striae, are striated (Fig. 3b), spaces between the striae being referred to as interstrial areas. Striae may bifurcate (Fig. 3a/2), converge adapically (Fig. 3a/4) or anastomose (Fig. 3a/5). Wrinkles commonly anastomose.

\section{Polygonal cross-sections and concave linear features}

In many cases, mosasaur teeth are characterised by polygonal horizontal cross-sections. The sides of these polygons may be flat, concave or convex, and the edges separating them may be marked by primary striae. These features have been described by various terms in the past, such as prisms, facets and flutes. Basically, a tooth with a polygonal cross-section can be described as prismatic (Figs $3 \mathrm{c}-\mathrm{g}$ ). The polygon faces can be characterised as prism faces, which may be flat (Fig. 3c) or convex (Fig. 3d). The term 'prism' for these faces (e.g. see Lingham-Soliar, 1995) is incorrect semantically because, in geometrical terms, a prism is a three-dimensional body, not a face of this body. When bordered by primary striae the faces are facets (syn. flutes). Facets may be superimposed on wider prism faces (Fig. 3e), which is an important reason for the terminological discrimination between these two features. Facets may be concave (Fig. 3f) or flat-bottomed (Fig. 3g). When the delimiting striae are densely spaced, facets and simple striation may be difficult to discern.

\section{Dental functional morphology and trophic guilds}

Massare (1987) defined seven trophic guilds for marine reptiles on the basis of a qualitative placement of tooth morphologies in a ternary system spreading between (1) slender, pointed, piercing teeth, (2) blunt, robust teeth, increasingly suitable for
A

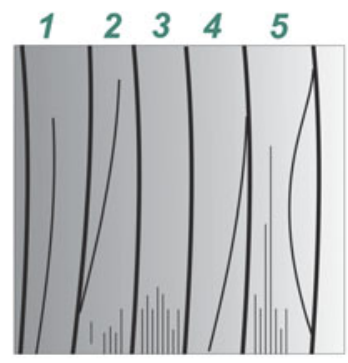

B

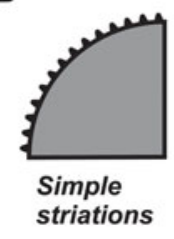

E

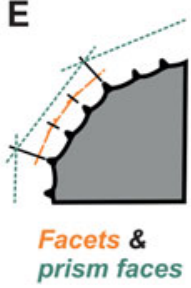

c

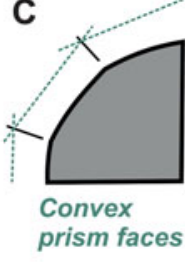

$\mathbf{F}$

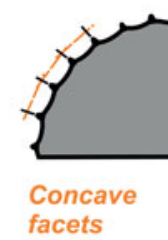

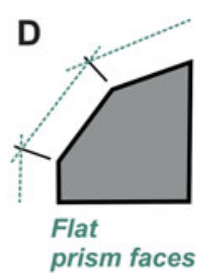

G

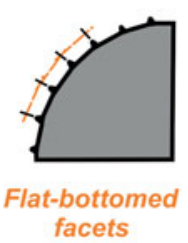

Fig. 3. Terminology of enamel structures and tooth crown geometries adopted in this paper. A, Striation hierarchy and patterns (on a schematic enamel surface): 1, primary and secondary striae; 2, primary stria bifurcating adapically into secondary stria, tertiary striae at the base; 3, primary and tertiary striae; 4, primary stria converging adapically with secondary stria; 5, primary stria anastomosing into secondary stria, tertiary striae at the base. $B-G$, Polygonal cross-sections and concave linear features (schematic cross sectional quadrant of tooth crown): $B$, simple striations; $C$, convex prism faces; $D$, flat prism faces; $E$, concave facets superimposed to prism faces; $F$, concave facets; $G$, flat-bottomed facets. 
crushing, and (3) sharp, robust cutting teeth. While widely adopted also for mosasaurs (Massare, 1987; Schulp et al., 2006; Ross, 2009), this scheme has some drawbacks with regard to strongly labiolingually compressed tooth crown morphologies. Inclusion of all degrees of tooth crown compression in bicarinate, 'robust' teeth in the 'cutting' guild will result in poor functional resolution for many mosasaur taxa (e.g. Schulp et al., 2006: fig. 8). Thus, we here propose to modify the scheme by introduction of an eighth guild, 'cut $\mathrm{II}^{\prime}$, in which the teeth are characterised by strong labiolingual compression (Fig. 4A). 'Cut' (sensu Massare, 1987) is here renamed to 'cut I' and typical examples, such as marginal teeth of Mosasaurus spp., are shifted towards the 'crunch' side on the 'crunchingcutting' axis for the labiolingual expansion. In this model, the 'piercing-cutting' axis is defined mostly by a mesiodistal expansion and acquisition of serrated carinae from 'pierce I' towards 'cut II'.

\section{Systematic palaeontology}

\section{Institutional abbreviations}

CAUK - Institut für Geowissenschaften der ChristianAlbrechts-Universität, Kiel, Germany; GZG.V. - Vertebrate collection, Geowissenschaftliches Zentrum der Universität Göttingen, Germany; IRSNB - Institut Royal des Sciences Naturelles de Belgique, Brussels, Belgium; MNHN - Muséum Nationale d'Histoire Naturelle, Paris, France.
A

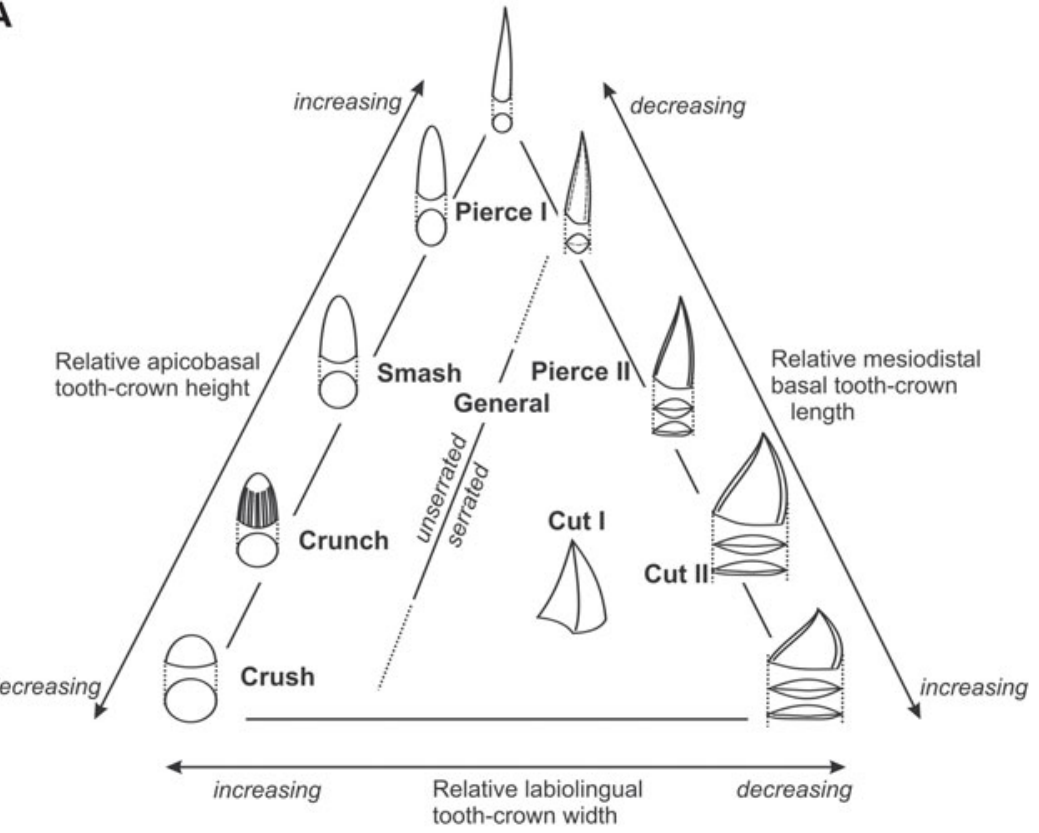

B

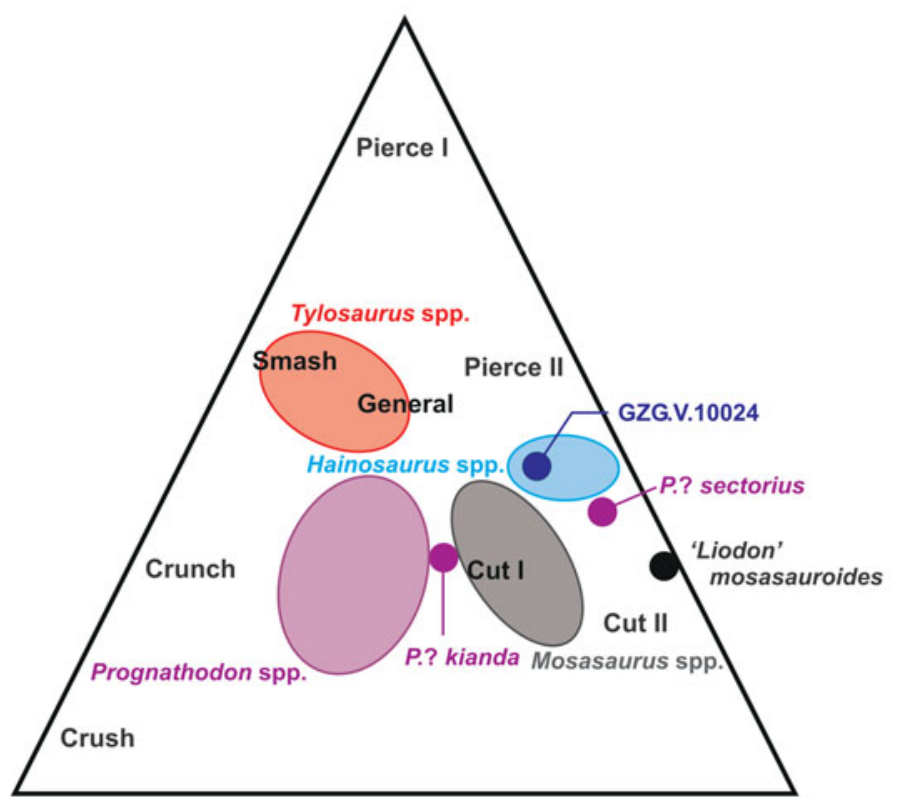

Fig. 4. Classification of trophic guilds in mosasaurs, based on Massare (1987) and Schulp et al. (2006), modified to represent morphological trends in tooth crown shape. The ternary system is defined by height/length and height/width ratios of the tooth crowns. This results in the proposal of a new 'cut II' guild for laterally strongly compressed, blade-shaped teeth, while 'cut I' (= 'cut' in Massare, 1987) retains a labiolingually expanded crown with cutting carinae. A, Modified ternary diagram with qualitative definition of guilds and typical representatives of shapes, based on Schulp et al. (2006). The occlusal view of the teeth on the right side is shown to include symmetrical and asymmetrical cross-sections. B, approximate position attained by various mosasaur taxa discussed in the text within the modified Massare classification (data from Gaudry, 1892; Massare, 1987; Schulp et al., 2006; pers. obs.). Note the shift in trophic guild assignment from 'smash/general' in Tylosaurus spp. towards 'pierce II/cut II' in Hainosaurus spp.. P.?: Prognathodon? 
Reptilia Laurenti, 1768

Squamata Oppel, 1811

Platynota Camp, 1923

Pythonomorpha Cope, 1869

(emend. Lee \& Caldwell, 2000)

Family Mosasauridae Gervais, 1853

Subfamily Tylosaurinae Williston, 1895

Genus Tylosaurus Marsh, 1872

Tylosaurus sp.

(Fig. 5)

v 1892 Mosasaurus? Alseni sp. n. - Stolley: p. 223, pl. VII, fig. 1. (nomen dubium)

v 1929 Mosas. (?) Alseni Sт. - Klähn: p. 59.

v 2014 Mosasaurus? alseni Stolley, 1892 - Sachs et al. doi: 10.1017/njg.2014.16, fig. 5B.

\section{Material}

Syntypes of Mosasaurus? alseni Stolley, 1892: CAUK G-K-588, a marginal tooth crown; CAUK without number, marginal tooth crown. From the 'Quadratenkreide' (Stolley, 1892), which in current terminology would correspond to the Lägerdorf Formation, latest Santonian to latest Early Campanian (Gonioteuthis granulata to G. quadrata gracilis/Belemnitella mucronata belemnite zones; Niebuhr, 2010) of the Alsen chalk-pit near Lägerdorf, Schleswig-Holstein, northern Germany.

\section{Marginal tooth crowns}

CAUK G-K-588 (Fig. 5A-F) is a shed, gently postero-lingually recurved tooth crown, with an ovate cross-section, highly asymmetrically divided into a gently convex labial and a deeply convex (Ushaped) lingual side by mesial and distal carinae. The mesial carina extends from the apex to the base of the tooth crown and bears minute serrations. The distal carina is distinct only in the apical third of the crown, curves labially and is adorned with much coarser serrations than the mesial carina. In the basal two-thirds of the tooth crown it effaces, becoming a faint, unserrated stria. Due to the asymmetry of the cross-section, the labial face corresponds only to about one-third of the basal circumference of the crown. In the basal third of this face about 8-10 narrow concave facets are present, separated by primary striae. Apically this number is reduced to four or five concave facets due to the fact that striae efface in between and the apical third of the labial face is smooth. The lingual face exhibits c. 17 narrow concave facets with the separating primary striae, occasionally bifurcating into, or converging with, short secondary striae along their length. Striation and faceting efface apically and the apical third of the tooth crown is nearly smooth, except for faint tertiary striae. Those are numerous and often anastomose near the base but decrease strongly in density apically.

The second, unnumbered CAUK tooth crown (Fig. $5 \mathrm{G}-\mathrm{K}$ ) is slightly less asymmetric in cross-section than CAUK G-K-588, although the lingual face still is much more convex than the labial one, occupying about $60 \%$ of the basal circumference. The tooth crown is recurved lingually, and lingual and labial faces are separated by carinae. Both carinae are finely serrated and the mesial carina extends along the whole apicobasal height of the crown, while the distal one effaces at mid-height from the apex into a faint, unserrated stria. The basal half of the labial face bears six to eight shallow and narrow facets, separated by primary striae, effacing towards a nearly smooth apex. Additionally, the labial face is very gently prismatic, with about three prism faces onto which the narrow facets are superimposed. The lingual face is covered in its basal half by 13-15 shallow facets, smoothing towards the apex, and by numerous partially anastomosing tertiary striae, which decrease in density but persist to the apex. A part of the labial face is covered by a patch of glue.

\section{Comparisons and remarks}

Both tooth crowns show characters which have been considered diagnostic for the genus Tylosaurus (see Lindgren \& Siverson, 2002), such as the stout morphology, weak recurvature, ovate crosssection with convex lingual and labial faces, occupying highly unequal sectors of the circumference, presence of relatively shallow, yet numerous, facets and distinct, fine tertiary striations, especially near the crown base. In fact, morphologically, they are nearly indistinguishable from the marginal teeth of Tylosaurus ivoensis (Persson, 1963) and T. gaudryi (Thevenin, 1896) from the late Early Campanian of Sweden and the Late Santonian-Early Campanian of France, respectively (Lindgren \& Siverson, 2002). The only differences appear to be the coarser serrations on the distal carina of CAUK G-K-588, the persistence of tertiary striae apically to mid-height and the weak prismatic appearance of the labial face in the second, unnumbered CAUK specimen (although the latter seems to be present also in some teeth of $T$. ivoensis, compare Lindgren \& Siverson, 2002: fig. 7/1a). Other differences, also between the present tooth crowns, can either be ascribed to their respective position in the jaws or are within the range of morphology exhibited by the much larger Swedish sample (Lindgren \& Siverson, 2002).

The posterolingual recurvature and discontinuous distal carina on CAUK G-K-588 suggests a rostral position in the dentary or premaxillary. The second CAUK tooth apparently had a more posterior position.

Stolley (1892) described both tooth crowns as syntypes of a new species, Mosasaurus? alseni. He provided a detailed and comprehensive description, although he treated both specimens as if they were identical. Additionally, he supplied an illustration of CAUK G-K-588 (Stolley, 1892: pl. VII, fig. 1). In his discussion he compared the teeth mostly to those of Mosasaurus and 'Leiodon', noting the circular cross-section and the striated and faceted surface as main distinguishing features, respectively. He also stated that the teeth are different from 'Zähnen amerikanischer Pythonomorphen' ('teeth of American pythonomorphs') 
A1

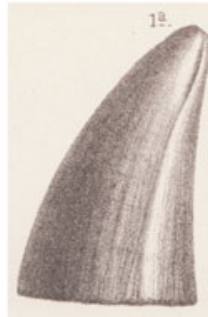

B1

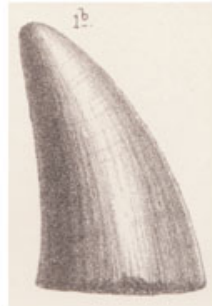

C1

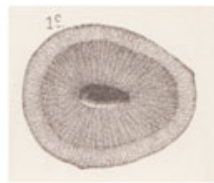

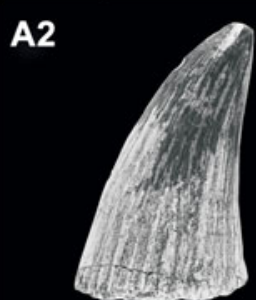

D
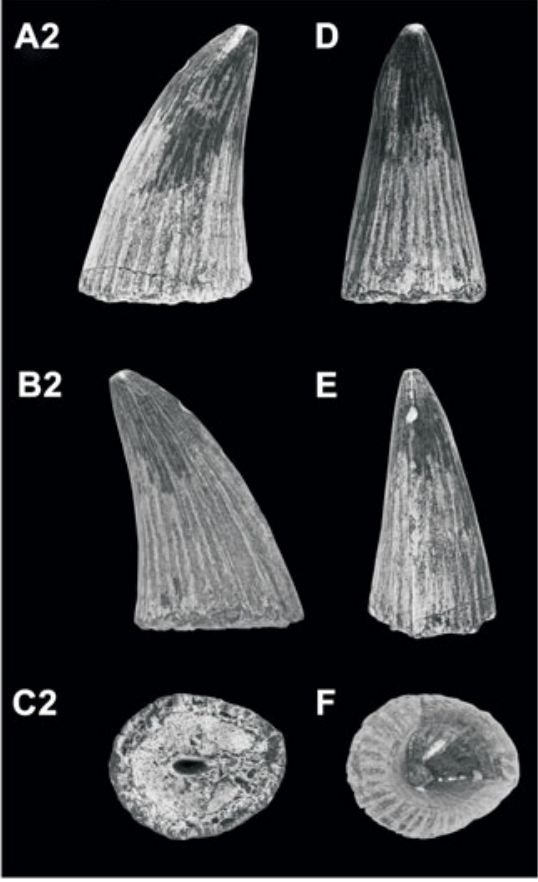

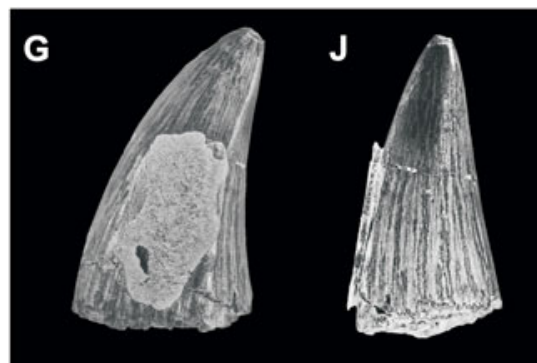

H

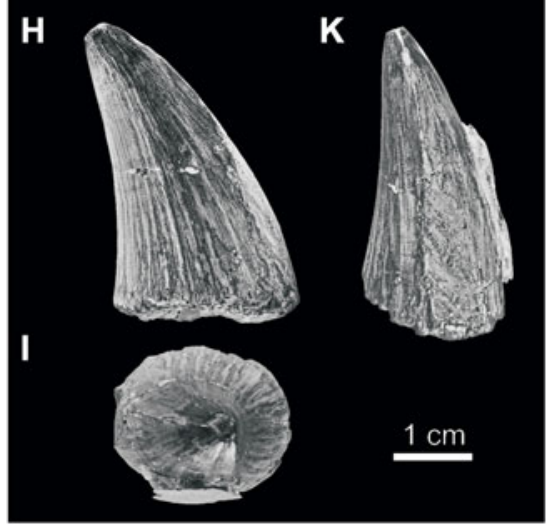

Fig. 5. Tylosaurus sp. (= Mosasaurus? alseni Stolley, 1892), lateral tooth crowns, Lägerdorf Formation, latest Santonian to Early Campanian of Lägerdorf, Schleswig-Holstein, northern Germany. A-F, CAUK G-K-588 in (A) labial, (B) lingual, (C) basal, (D) distal, (E) mesial. (F) occlusal aspects; A1-C1: original figure of the specimen by Stolley (1892: pl. VII, fig. 1a-C) for comparison. G-K, CAUK unnumbered specimen in (G) labial, (H) lingual, (I) occlusal, (J) distal, (K) mesial aspect.

as well as from those of the 'neuerdings von Dollo beschriebenen Mosasauriden' ('mosasaurids recently described by Dollo'), referring to Dollo $(1882,1885 a, b, 1889,1890)$, although he did not provide a rationale for this claim. On the other hand, he did find similarities to an unnamed, fragmentary tooth from the Chalk Group of Norwich, England, figured and described by Owen (1850: 385, pl. XXXVII, fig. 14). He concluded that the specimens represent a new species, hesitatingly referring it to the genus Mosasaurus, yet he failed to give an explicit diagnosis of this new form.

Despite this, Stolley's nomenclatural act is fully valid under the regulations of the ICZN (1999). In fact, it might be argued that - in view of the large overlap in dental morphology Mosasaurus? alseni Stolley, 1892 constitutes a senior synomym of Mosasaurus gaudryi Thevenin, 1896 (now Tylosaurus gaudryi) and of Mosasaurus hoffmanni ivoensis Persson, 1963 (now Tylosaurus ivoensis), taking precedence. However, the taxonomic resolution of dental features below the genus level in Tylosaurus is not straightforward and should be only based on large samples. For a striking example, Lindgren \& Siverson (2002) reported that the lateral dentition of T. ivoensis and T. gaudryi overlap morphologically, although their pterygoid teeth are clearly distinct. Therefore, with the scant material at hand, we cannot determine safely whether 'M.?' alseni was a taxon different from T. ivoensis or T. gaudryi. In the light of the small database for 'M.?' alseni, it is considered to be a nomen dubium, and the syntypes are referred herein to Tylosaurus sp., awaiting the discovery of further specimens.
Genus Hainosaurus Dollo, 1885a

Hainosaurus sp.

(Figs. 6-9)

V 1910 Mosasaurus cf. mosasauroides (Gaudry) Pompeckj: 126, pl. 4.

v (partim) 1993 Leiodon mosasauroides Gaudry, 1892 Lingham-Soliar: 453.

$\mathrm{v}$

2000 Leiodon cf. mosasauroides Gaudry, 1892 Sachs: 37, fig. 2.

? 2003 Plioplatecarpinae sp. A - Machalski et al.: 405, fig. 9B.

v 2005 Oberkiefer (Leiodon) ... - Reich et al.: fig. 12c.

? 2005 Hainosaurus sp. 1 - Jagt et al.: 303, 304, fig. 1.

? 2005 Hainosaurus sp. - Lindgren: 1159, fig. 2.

v 2006 Hainosaurus sp. - Hornung \& Reich: 40.

v 2014 Oberkiefer (Hainosaurus) - Frenzel et al.: fig. 5c.

v 2014 Cranial remains of a mosasaur - Sachs et al. doi: 10.1017/njg.2014.16, fig. 6B.

\section{Material}

GZG.V.10024 (Pompeckj, 1910; Sachs, 2000; Figs 6-9), a fragmentary right maxillary with associated fragmentary left postorbitofrontal, indeterminate cranial fragments, two pterygoid 

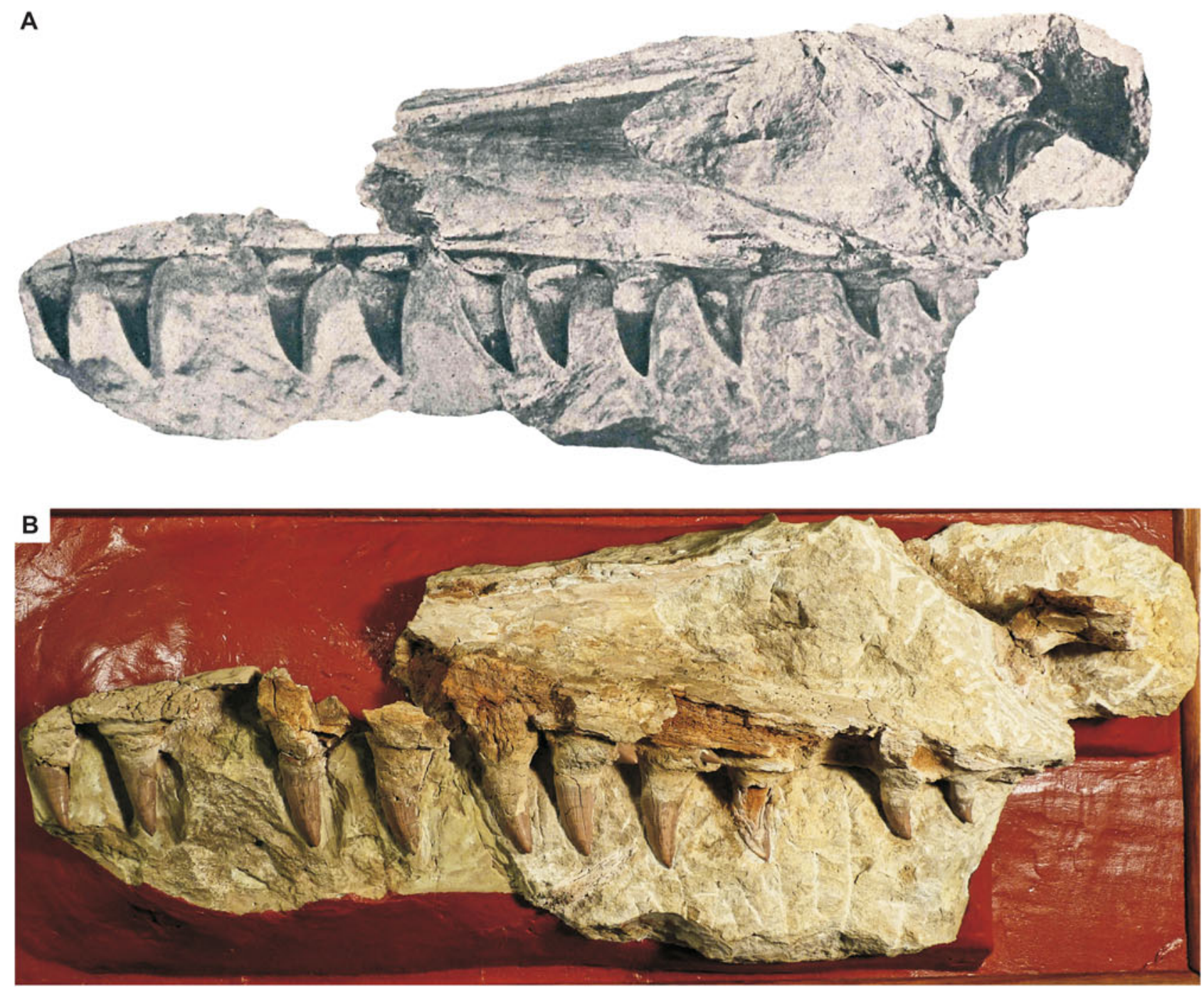

C

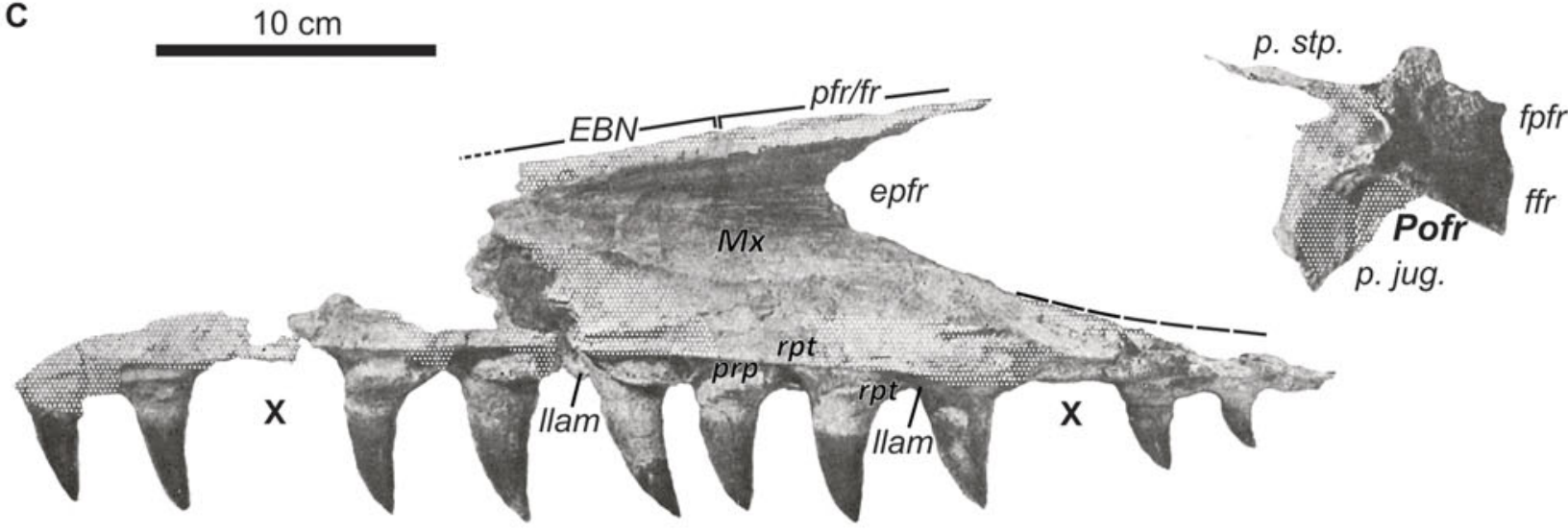

D

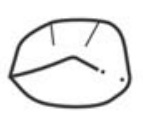

2

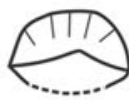

4

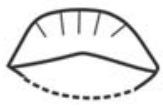

5

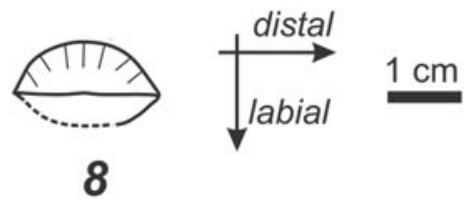

Fig. 6. Hainosaurus sp., GZG.V.10024, associated cranial elements, Haldem Member, Stemwede Formation, Late Campanian of Stemwede-Haldem, North-Rhine Westphalia, northwestern Germany: A, as figured by Pompeckj (1910: pl. IV); B, as presently preserved; C, interpretative sketch based on the figure by Pompeckj (1910); D, schematic occlusal aspect of teeth (tooth positions 2, 4, 5 and 8). EBN, Position of external bony naris; epfr, caudal embayment for the rostral wing 
teeth, plus a fragmentary cervical vertebra (lost) and rib fragments (lost) of a single individual from the latest Campanian (Bostrychoceras polyplocum ammonite zone, Pompeckj, 1910), in current terminology the Haldem Member, Stemwede Formation (Dölling et al., 2006, 2010) at the Stemweder Berg, vicinity of Stemwede-Haldem, near Lemförde, northeastern North-Rhine Westphalia, northwestern Germany.

The same locality has yielded some ribs and postcranial fragments of an indeterminate mosasaur, now housed in the collections of the Aquazoo Museum, Düsseldorf (Sachs, 2000).

The specimen is mounted on a block of matrix and can almost exclusively be observed from the medial/lingual side (Fig. 6). However, some of the teeth are more or less freed from the surrounding matrix and allow at least a partial assessment of their labial side and cross-section. During conservation work a few years ago, the postorbitofrontal was in part removed from the matrix, but was subsequently refitted to the mount. The pterygoid tooth and a few small indeterminate bone scraps have been kept isolated. The poorly preserved cervical vertebra and rib fragments, mentioned by Pompeckj (1910: 122), are now missing from the material. Judging from Pompeckj (1910: pl. IV) the specimen has suffered from some damage since its discovery, especially in the dorsal and rostral regions of the maxillary and along the dental shelf (Fig. 6C).

\section{Maxillary}

The right maxillary (Fig. 6) is only fragmentarily preserved. Most of the rostral part is missing and the dorsal and caudal margins are damaged to some degree. The oral margin posterior to tooth position 5 is damaged now, but was originally preserved (Pompeckj, 1910). A slightly thickened, rounded dorsal margin, extending from above tooth positions 5 to 7, probably represents the lateral margin of the external naris. At the level of tooth position 7 it slightly bulges posteriorly and while now damaged and almost inconspicuous, the illustration by Pompeckj (1910) clearly shows a longitudinal groove stretching along the margin to the caudal end of the processus nasalis of the maxillary. This groove is considered to represent the contact to either the frontal or the processus nasalis of the prefrontal, depending on the configuration of the skull roof (Russell, 1967; Lingham-Soliar, 1992). The external bony naris would therefore have extended caudally to a level between tooth positions 7 and 8 .

The caudal part shows a deep, rounded-triangular excavation, opening caudally and reaching to tooth position 8 rostrally. The margin of this excavation appears to be intact for most of its length and not to result from damage (contra Pompeckj, 1910).
It is nearly smooth, although showing slight serrations in places, and represents the contact with the triangular rostrolateral 'wing' of the prefrontal.

As is common in mosasaurids, the tooth row is situated on a robust ventromedian shelf ('buttress' sensu Russell, 1967). This shelf bears a slight ventral emargination medially to the teeth (preserved above tooth position 7, 'parapet' sensu Russell, 1967) and also one laterally to the tooth row (Pompeckj, 1910), although the latter is almost entirely missing due to damage or is otherwise obscured. Above tooth positions 4 to 5 it shows a medial vertical sutural surface for the contact with the vomer, which passes caudally into a horizontal groove (no longer preserved) above tooth position 6 . The main body of the maxillary forms an almost right angle with the toothbearing shelf. The oral margin of the maxillary is very gently concave. The general proportions of what is preserved from the maxillary suggest a gently tapering, low muzzle with proportionally large teeth.

\section{Postorbitofrontal}

Most of the left postorbitofrontal (Fig. 7) is preserved together with the right maxillary of GZG.V.10024, turned by about $180^{\circ}$ in position relatively to the latter element. The postorbitofrontal was correctly identified by Pompeckj (1910), but referred to as a possible pterygoid by Sachs (2000). It consists of a subpentagonally outlined plate of bone from which a robust, mediolaterally broad, distally tapering processus jugalis projects ventrally and an elongate processus supratemporalis caudally. Most of the distal and lateral processus jugalis is broken away and its base is pierced posteromedially by a small (1.5 mm diameter) foramen. The processus supratemporalis is a thin, narrow strap of bone, extending from the dorsocaudal margin of the processus jugalis with a medial and ventral off-set relative to the lateral margin of the bone. It is incomplete caudally and longitudinally twisted by about $50^{\circ}$. Its lateral and medial margins are damaged or covered by matrix, respectively. The thinness of the bone suggests that it overlapped the rostral process of the squamosal for most of its length but the ventrally facing contact surface is obscured by matrix.

The dorsal surface of the postorbitofrontal is damaged and the thin substantia compacta lost, revealing a highly cancellous substantia spongiosa. The anteromedial and medial margins of the postorbitofrontal show two separate sutural faces, the rostral one of which is the best preserved. It forms a transverse, deeply excavated, locally vertically striated, horizontal notch

of the prefrontal; ffr, facet for contact with frontal; fpfr, facet for contact with prefrontal; llam, ventrolabial lamina on the maxillary; Mx, right maxillary; . jug., processus jugalis; pfr/fr, medial contact to the prefrontal or frontal; Pofr, left postorbitofrontal; prp, medial parapet on the maxillary shelf; $p$. stp., processus supratemporalis; rpt, replacement teeth; $X$, position of missing teeth; white dotted area, damage to the specimen since 1910. 

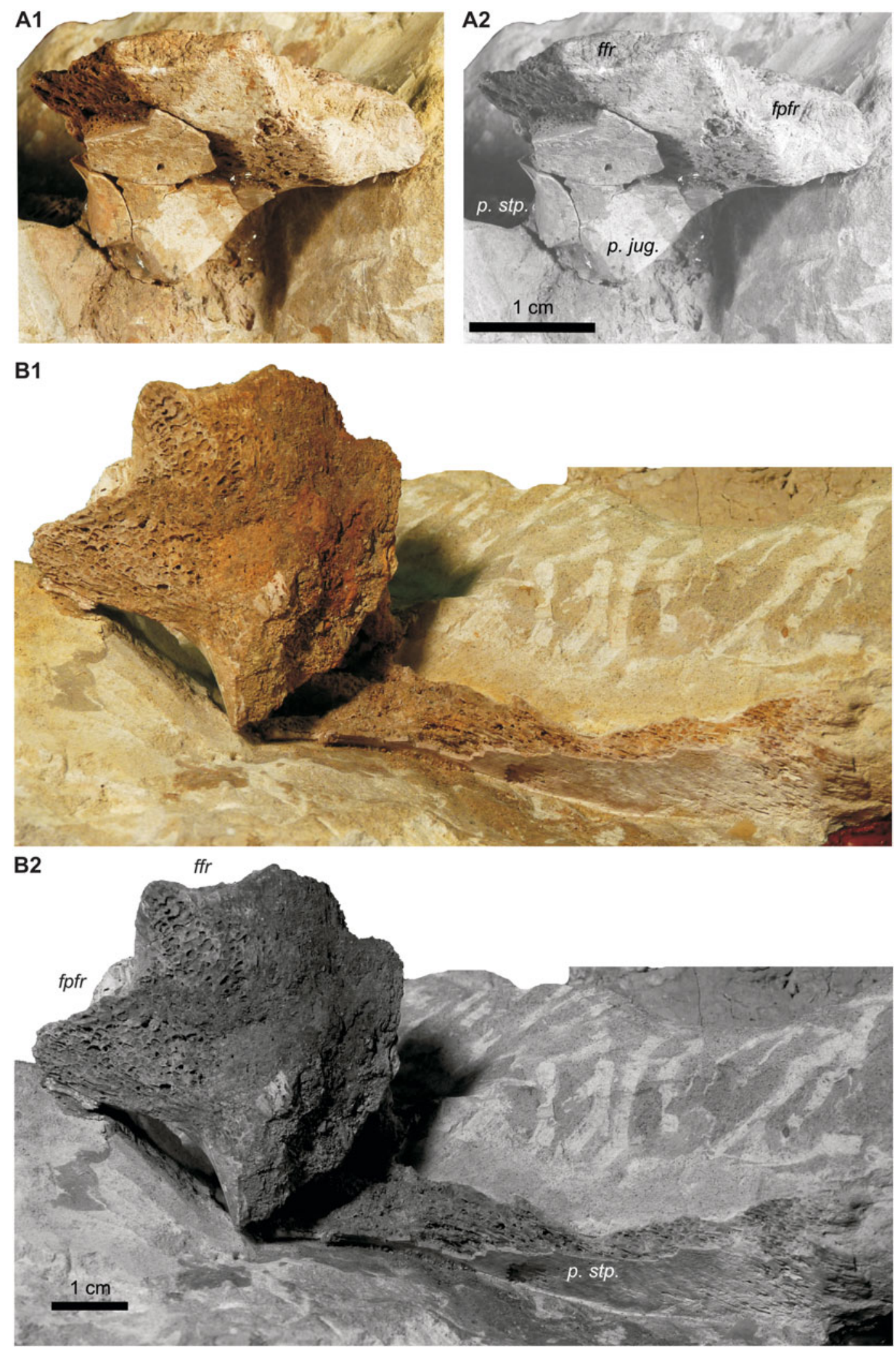

Fig. 7. Hainosaurus sp., GZG.V.10024, fragmentary left postorbitofrontal: A, medial aspect; B, dorsal aspect; for abbreviations see Fig. 6.

in the slightly dorsoventrally thickened rim of the bone. The second, situated at the medial margin of the postorbitofrontal, is slightly concave. The margin of the bone is not thickened. The caudomedially located contact to the parietal is damaged.
The number and configuration of the anteromedial and medial sutural faces in GZG.V.10024 show close similarities to that in Hainosaurus bernardi as described by Lingham-Soliar (1992: figs. 6 and 7). This implies that the rostralmost face received 
the caudoventral process of the prefrontal, which met the postorbitalfrontal caudally to exclude the frontal from the dorsolateral margin of the orbit. This interpretation is supported by the deep excavation and separation of the rostral sutural contact from the medial one. In taxa where the prefrontal and postorbitofrontal are separated by the frontal (e.g. Clidastes spp., compare Russell, 1967), the rostral contact of the postorbitofrontal to the frontal is smooth and tapers laterally, passing continuously into the medial contact. The medial sutural face contacted the ventrolateral margin of the frontal. Because of poor preservation it is not clear whether there was a processus prefrontalis, overlapping dorsally onto the prefrontal as in other tylosaurines (Russell, 1967; Lingham-Soliar, 1992; Lindgren, 2005), or not.

\section{Maxillary dentition}

The maxillary of GZG.V.10024 bears at least 12 tooth positions, 10 of which preserve the teeth. The designation of the first tooth as position 1 is conjectural as nothing of the premaxillaries is preserved. Yet, based on the overall morphology of the tooth row and maxillary it appears improbable that the total number of teeth in the maxillary exceeded 12. Tooth positions 3 and 10 are empty and tooth 9 is very poorly preserved. For most teeth only the lingual surface is observable.

The tooth morphology (Figs $6 \mathrm{D}$ and $8 \mathrm{~A}-\mathrm{E}$ ) varies slightly along the tooth row. The rostral teeth (1-4) are gently labiolingually compressed, oval and decreasingly asymmetrical in cross-section with a more convex lingual side. More caudally the teeth first become more strongly compressed (5-7) and then again more oval in cross-section towards the end of the maxillary (8-12) and obtain a nearly symmetric cross-section. All teeth bear a mesial carina, extending from the base to the apex of the tooth crown. A weak distal carina is present on tooth 2, where it extends from the apex to about mid-height of the crown and a well-developed distal carina, running from the apex to the base of the tooth, is present on teeth 4-12. All carinae are minutely, weakly and irregularly serrated, the serrations are generally being slightly more conspicuous on the distal carinae. On teeth 1 and 2 the distal carina is substituted near the base by a rounded edge, separating the lingual from the labial side. All teeth are weakly prismatic, teeth 1-9 exhibit six to eight flat-bottomed facets on the lingual side, separated by weak primary striae. Each facet bears five to eight very faint secondary striae. Teeth 11 and 12 show three facets on the lingual side, also with seven to eight faint primary to secondary striae on each facet. In most teeth primary and secondary striae extend to about $50-60 \%$ of the crown height before effacing into a smooth apex. Only the lingual side of tooth 12 is covered for about $80 \%$ of its height in a dense array of secondary striae. A tertiary order of striation is present as very fine non-anastomosing striae, extending from the base to about $40-50 \%$ of crown height in teeth 1, 2 and 12 , and to about $20 \%$ in the other teeth on the lingual side.

The labial surface of tooth 2 is the only one that can be sufficiently observed; it appears to bear a similar number of facets to the lingual side, with slightly more pronounced primary striae. All tooth crowns are caudally recurved with an increasing degree of recurvature towards the distal end of the tooth row. Additionally tooth crowns 1 to 5 are slightly curved medially. The enamel shows a slight transverse light-and-darker colour banding, with bands c. 1-2 mm in width. The tooth bases are slender, cylindrical and have a slight constriction at the base of the enamelled crown. They contain replacement teeth in a posteromedially located socket. Replacement teeth are preserved at the bases of teeth 7 and 8 (Fig. 8F). Their smooth apices point caudoventrally, forming an angle of $15-25^{\circ}$ to the horizontal plane.

\section{Pterygoid dentition}

Two fragmentary pterygoid tooth crowns are preserved. The pterygoid teeth are small in comparison to the marginal dentition (i.e. the tooth crown height of the better-preserved specimen is $17 \mathrm{~mm}$, but may actually have been $19-20 \mathrm{~mm}$ when complete). The larger one (Fig. $8 \mathrm{G}$ and $\mathrm{H}$ ) is better preserved, while the smaller one is split parasagittally, with only a sector of the labial side still available for examination. The tooth crowns are slightly compressed and symmetrically oval in cross-section, short, with a slightly inflated base, tapering rapidly to a strongly distally and slightly lingually recurved apex. The enamel is covered by fine yet distinctive secondary striae (0.5-1 per $\mathrm{mm}$ ) that are intercalated by thin tertiary striae (2-3 per mm). On the smaller tooth about the apical third is smooth; in spite of this the ornament is uniform around the whole circumference in both teeth. The larger tooth possesses an unserrated weak mesial carina and a very short, vestigial, unserrated labial carina near the apex. The preserved labial face of the smaller tooth shows a very indistinct, smooth, edge-like lateral carina. The bony base is only preserved to some extent on the larger tooth; it is short and stoutly conical, passing continuously into the enamelled crown.

\section{Comparisons and remarks}

GZG.V.10024 was originally assigned by Pompeckj (1910), with some reservation, to the poorly known mosasaurine Liodon mosasauroides Gaudry, 1892, from the Maastrichtian of the French Pyrenees. Lingham-Soliar's (1993) synonymy list included GZG.V.10024 under L. mosasauroides, although that author did not further discuss this specimen. Sachs (2000) followed Pompeckj (1910) in being more cautious in identifying the specimen as $L$. cf. mosasauroides.

There are several issues surrounding these identifications. The holotype of 'L.' mosasauroides consists of a large snout 

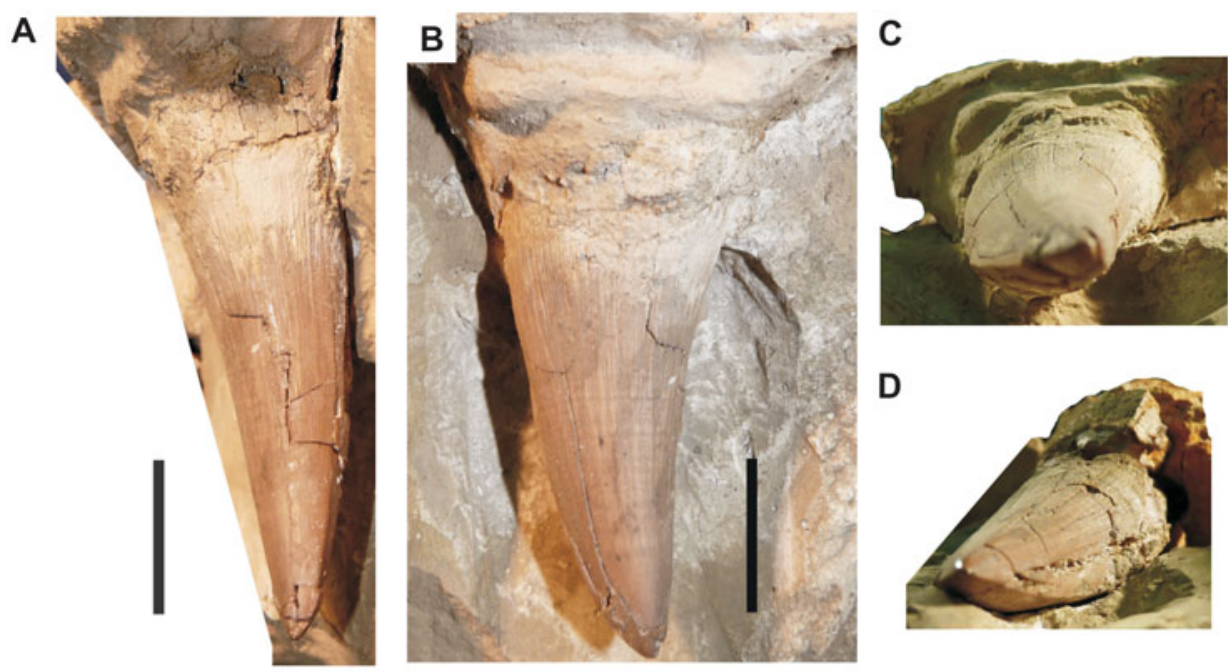

D
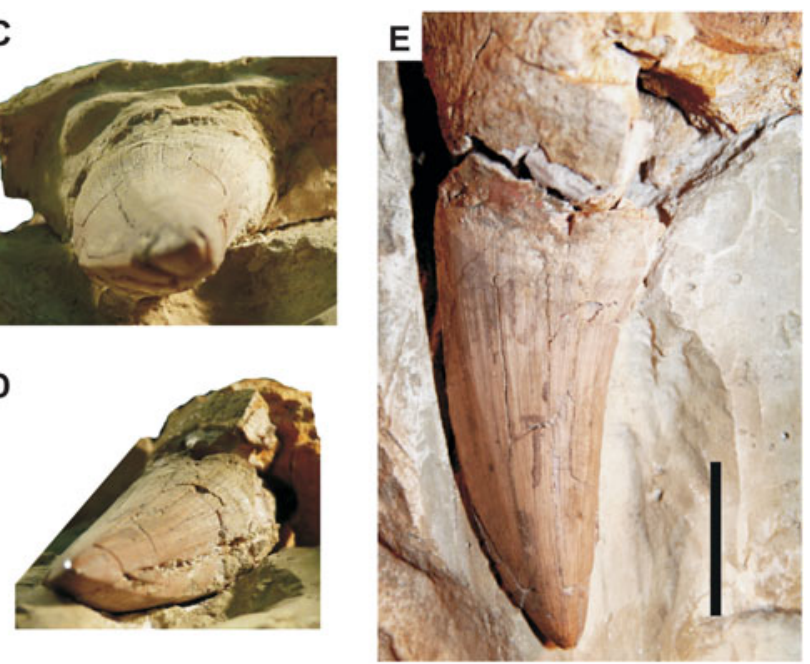

$\mathbf{F}$

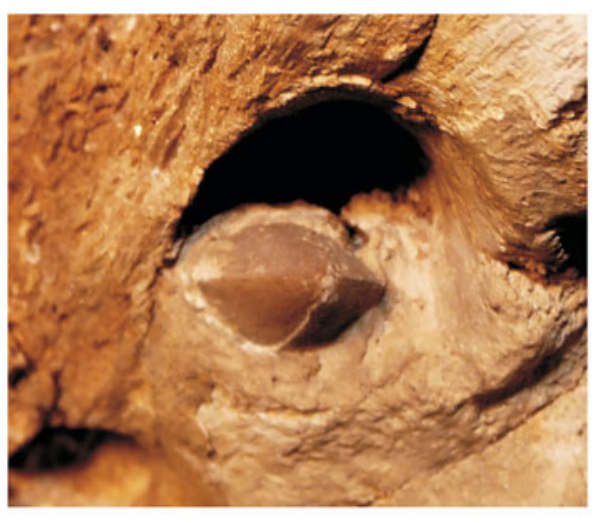

G

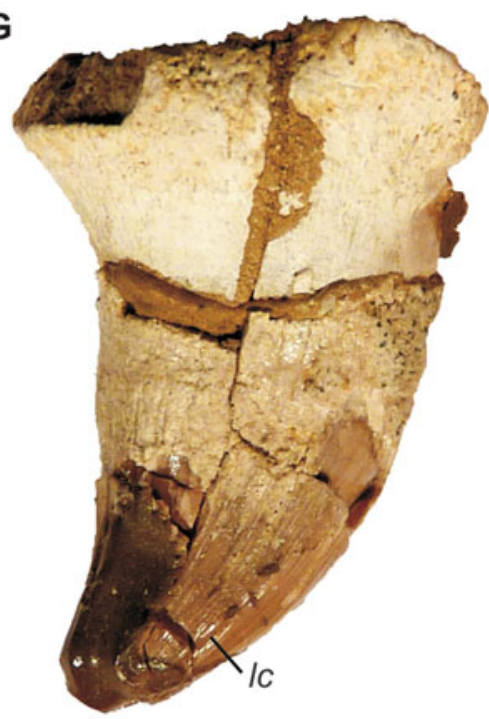

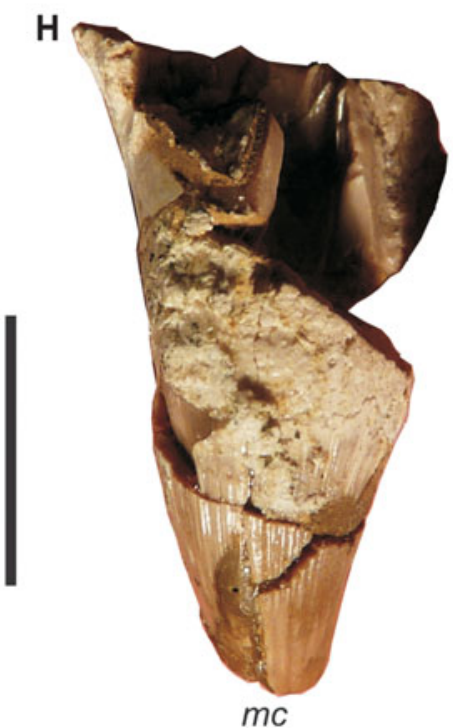

Fig. 8. Hainosaurus sp., GZG.V.10024, details of dentition: A-C, second maxillary tooth; A, mesial aspect; B, lingual aspect; C, occlusal/lingual aspect. D-E, fourth maxillary tooth; $D$, mesiolingual aspect; $E$, lingual aspect; $F$, replacement tooth in position 8. G, H, pterygoid tooth; G, labial aspect; $H$, mesial aspect; lc, vestigial labial carina; mc, weak mesial carina. Scale bars: $10 \mathrm{~mm}$ in A-E, $5 \mathrm{~mm}$ in F-H.

section, comprising an articulated fused premaxillary, maxillaries and dentaries (MNHM 1891-14; see Lingham-Soliar, 1993; Bardet, 2012) with a distinctive, highly trenchant dentition. Actually 'L.' mosasauroides has exceptionally strongly labiolingually compressed, but asymmetrically cross-sectioned tooth crowns, broadly triangular in lateral aspect, with smooth enamel, and a higher number of maxillary teeth (13) than GZG.V.10024 (Gaudry, 1892; Lingham-Soliar, 1993; Bardet, 2012). On the basis of these differences the latter cannot be assigned to 'L.' mosasauroides.

However, moderately recurved to upright tooth crowns with subequal lingual and labial faces, a subovate to moderately labiolingally compressed cross-section, several orders of striae commonly vanishing towards the apex and dense tertiary striae near the crown base are features generally held typical of members of the subfamily Tylosaurinae (Russell, 1967; Bardet, 1990;
Lingham-Soliar, 1992; Lindgren \& Siverson, 2002; Lindgren, 2004, 2005; Jagt et al., 2005).

Within this subfamily GZG.V.10024 shares the following dental characters with the genus Hainosaurus (see Lindgren \& Siverson, 2002; Lindgren, 2005): caudolateral teeth bicarinate with serrated carinae, labiolingually compressed with subequal lingual and labial faces, seven or eight weak facets on the lingual face, non-anastomosing second- and third-order striae at the base of the crown. In this genus, two nominal species are currently recognised (Lindgren \& Siverson, 2002; Lindgren, 2005; Martin, 2007, but see Bullard \& Caldwell, 2010), the type species $H$. bernardi and $H$. neumilleri Martin, 2007, from the Late Campanian of South Dakota, USA. In addition to these, further material, potentially at least partially representing unnamed species, has been referred to this genus (Lindgren, 2005; Jagt et al., 2005, 2006). Most characters of GZG.V.10024 are 
consistent with those described by Lingham-Soliar (1992) and Lindgren (2005) for $H$. bernardi. It is distinguished, however, from the type species in that the distal carina is missing from the first two maxillary teeth. Additionally, the anterolateral tooth crowns are slightly more inflated lingually and more asymmetrical than in $H$. bernardi. The most important differences are presented by the pterygoid teeth. GZG.V.10024 shows, at least on some pterygoid teeth, an indistinct, unserrated, mesial carina and a very weak, incompletely developed, unserrated, lateral (labial) carina. The ornament on the pterygoid teeth is uniform along the entire circumference and the teeth are slightly recurved medially. In $H$. bernardi and Tylosaurus spp. (with the exception of T. gaudryi), the pterygoid teeth bear two distinct lateral carinae, which are serrated in $H$. bernardi and have separate, differently ornamented, rostral and caudal sides (Lindgren \& Siverson, 2002; Lindgren, 2005). Mesial and distal carinae are present in $T$. gaudryi (see Thevenin, 1896; Lindgren, 2005). Finally, the ventrally and slightly laterally arched supratemporal bar is different from $H$. bernardi, in which the corresponding element is straight (LinghamSoliar, 1992). GZG.V.10024 differs from $H$. neumilleri by the presence of more distinctively prismatic lateral teeth and probably more flattened labial faces in the marginal teeth of the latter (Martin, 2007).

Another character supporting assignment of GZG.V.10024 to the Tylosaurinae is the deep triangular embayment of the caudal margin of the maxillary, receiving the rostral triangular wing of the prefrontal. This feature was not depicted in the skull reconstruction of $H$. bernardi by Lingham-Soliar (1992) but can be seen in the holotype (IRSNB R23 [1564], LinghamSoliar, 1992: pl. I, fig. A) and in the reconstruction by Dollo (1888: pl. I, fig. 2). Although the prefrontal wing is absent from IRSNB R23, the caudal margin of the maxillary seems to be largely intact, a view supported by the configuration of the prefrontal-maxillary contact in the genus Tylosaurus (e.g. see Russell, 1967; Everhart, 2005).

GZG.V.10024 probably represents a still undescribed species of Hainosaurus (Fig. 9), but the paucity of the material leads us to refrain from the introduction of a new nominal taxon until better-preserved material becomes available.

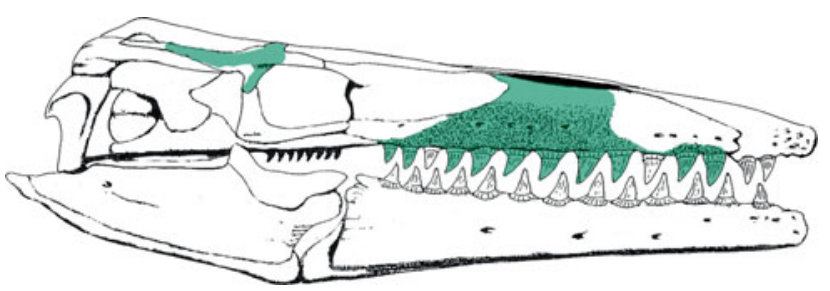

Fig. 9. Hainosaurus sp. from the Late Campanian of Stemwede-Haldem, reconstruction based upon $\mathrm{H}$. bernardi Dollo, 1885a (after Lingham-Soliar 1992, modified). Preserved parts in green, left postorbitofrontal mirrored to the right side.
Isolated teeth referred to Hainosaurus 'sp. 1 ' from the Late Campanian of Poland (Machalski et al., 2003; Jagt et al., 2005) and the Early Campanian of Sweden (Lindgren, 2005) show a close resemblance to the posterolateral teeth of GZG. V.10024, despite a lower number of facets on the lingual face (three to nine rather than nine to twelve) in the latter. However, the teeth from Poland and Sweden are significantly smaller than those of GZG.V.10024. This fact, coupled with the observation that a decrease in the number of facets during ontogeny has been proposed earlier for the genus Mosasaurus by Mulder et al. (2004) let it appear reasonable that the former represent juvenile or subadult specimens of the same species as GZG.V.10024 (compare Lindgren, 2005).

\section{Discussion}

\section{The validity of Hainosaurus Dollo, 1885a}

The distinction between the closely related genera Tylosaurus and Hainosaurus has been based on relatively few cranial, dental and vertebral characters (Dollo, 1885a,b; Lingham-Soliar, 1992; Lindgren \& Siverson, 2002; Lindgren, 2005). Lindgren $\&$ Siverson (2002) reduced the supposed differences between both genera to (1) labio-lingually compressed lateral teeth with (2) minutely serrated mesial and distal carinae in Hainosaurus, while they are ovate in cross-section, asymmetric and with unserrated carinae in Tylosaurus; (3) pterygoid teeth with serrated carinae in Hainosaurus, while they are unserrated in Tylosaurus; (4) a small suprastapedial process of the quadrate in Hainosaurus, while it is large in Tylosaurus; (5) a large infrastapedial process of the quadrate in Hainosaurus, while it is larger in Tylosaurus; (6) a quadrangular outline of the quadrate in lateral aspect in Hainosaurus, whereas it is more circular in Tylosaurus; (7) the femur in Hainosaurus is longer than the humerus, while being subequal in length in Tylosaurus; (8) a larger number of vertebrae between the cranium and the chevron-bearing caudals in Hainosaurus than in Tylosaurus; and (9) anteriorly situated intermediate caudal centra in Hainosaurus that are wider and shorter than in Tylosaurus.

However, following a revision of North American material previously referred to Hainosaurus, Bullard \& Caldwell (2010) suggested that most of the cranial and postcranial features were ambiguously dispersed among the two genera and not suitable to distinguish between them, leading to the conclusion that Hainosaurus might be a junior synonym of Tylosaurus (see also Jimenez-Huidobro \& Caldwell, 2012).

While we are not prone herein to present a complete reassessment of Hainosaurus bernardi, the Belgian type species of the genus (Dollo, 1885a), we opt to retain Hainosaurus as a valid genus for several reasons. Most important is the strong modification of the lateral and pterygoid dentition, which is clearly linked to a change in the choice of prey and probably also of feeding behaviour (see also Lingham-Soliar, 1992; Fig. 4B). 
During the Campanian, the plesiomorphic condition (relative to Hainosaurus) of robust caudolateral, conical, laterally only slightly compressed, asymmetric, unserrated tooth crowns in Tylosaurus spp., which belong functionally to the 'general' guild (sensu Massare, 1987; Fig. 4), to the almost symmetrical, laterally strongly compressed, nearly blade-like posterior marginal tooth crowns in Hainosaurus, functionally referable to the 'cut II' guild (Fig. 4). Similar changes occurred in the pterygoid teeth, which became more recurved (caudomedially) and in some species of Hainosaurus also serrated. This character is plesiomorphic in GZG.V.10024, which lacks serrations on the pterygoid teeth at all, as well as distinct carinae, suggesting that the modification of the pterygoid dentition occurred phylogenetically later than that of the lateral dentition. Another character probably connected to these major changes of the dental apparatus is the presence of a thin bony lamina protruding ventrally and labially to the dentigerous buttress from the maxillary to form a straight oral margin of the maxillary. Such a lamina, although delicate and easily damaged, is present in the type and referred material of $H$. bernardi (see Lingham-Soliar, 1992; Martin, 2007: figs. 3e and f), as well as in GZG.V.10024. In Tylosaurus, the oral margin of the maxillary is more or less confluent with the labially bulging tooth bases, leaving laterally open interdental reception grooves for occlusion with the dentary teeth (e.g. Everhart, 2005).

While differentiation in the dentition may be regarded a minor character in contrast to the extensive overlap of osteological characters between both genera, we consider them important enough to warrant distinction between Tylosaurus (sensu stricto) and derived forms with a trenchant dentition. The hierarchical level of such a distinction may be a matter of discussion. Nonetheless we propose Hainosaurus to be retained as a valid genus (instead of, for example, a more informal specialised 'species group' of Tylosaurus) because it appears despite the scarce remains - that tylosaurine mosasaurs with a trenchant dentition form a clade of several species which also show some degree of phylogenetic trend, increasing the pronounciation of typical characters of the genus from the Early Campanian through the Late Maastrichtian (Jagt et al., 2005, and discussion below). For similar reasons we propose to consider $H$. neumilleri at least tentatively as valid because its holotype, the incomplete remains of a tylosaurine, is undoubtedly associated with lateral teeth characteristic of Hainosaurus (but not of $H$. bernardi, see Martin, 2007). We are also aware that there might be the caveat that remains of Tylosaurus-like tylosaurines which do not include teeth (e.g. Tylosaurus capensis Broom, 1912, see Lingham-Soliar, 1992) may not be identifiable at genus level.

As has been recently shown, for example by Young \& Andrade (2009) and Young et al. (2012) for marine crocodilians and Knutsen (2012) for pliosaurs, niche-partitioning by developing a variety of tooth morphologies linked to different feeding habits strongly augments the diversification of marine reptile clades, which show otherwise relatively little variation in the skeletal bauplan. It also provides an explanation for the sympatriticity of a wealth of large-bodied, generally similar mosasaurs in the Late Cretaceous (see also Ross, 2009). We therefore support the call by Lindgren \& Siverson (2002, $2004)$ and Lindgren $(2004,2005)$ to value the dental morphology of derived mosasaurs as a taxonomic tool at low systematic levels, given their stringent analysis and description of more complete types for reference.

\section{The history of tylosaurines in Europe}

Teeth of Tylosaurus sp. from the Coniacian/Santonian of Lonzée, Belgium (Lindgren \& Siverson, 2002) may represent the oldest tylosaurines in Europe. Very poorly preserved and undiagnostic remains from the same stratum and locality have been described as Hainosaurus lonzeensis Dollo, 1904, but this taxon has unequivocally been considered a nomen dubium (Nicholls, 1988; Lingham-Soliar, 1992; Lindgren \& Siverson, 2002).

The Early Campanian saw some diversification of the genus Tylosaurus across Europe, with the slightly better known T. gaudryi from northeastern France and T. ivoensis from southern Sweden (Lindgren \& Siverson, 2002; Bardet, 2012). Tylosaurus sp. from northern Germany (Stolley, 1892; the present paper) also falls into this temporal range. During the Early Campanian, Hainosaurus appeared for the first time with $H$. sp. from southern Sweden (Lindgren, 2005) and northeastern Belgium (Jagt, 2005). It may have also been present in northern Spain (Bardet et al., 1997: fig. 3/1 [as Mosasaurus lemonnieri Dollo, 1889]).

The stratigraphically youngest European occurrence of Tylosaurus sp. was recorded from the Late Campanian of northern Spain (Bardet et al., 2006). Widespread, albeit scanty remains of Hainosaurus sp. are known from the Late Campanian of France, England, northwestern Germany and Poland (Jagt et al., 2005; Bardet, 2012; the present paper), and possibly of northern Spain (Bardet et al., 1997: fig. 3/4 [as Mosasaurus sp.]). Mulder \& Mai (1999) referred a partial parietal (von Meyer, 1860) from the early Late Campanian of Belgium to $H$. cf. bernardi, citing it as the potentially oldest occurrence of the species. However, the absence of teeth in that material makes such an identification slightly ambiguous.

The best record of Hainosaurus to date is from the Early Maastrichtian Ciply Phosphatic Chalk Formation of Belgium with $H$. bernardi. In the Late Maastrichtian H. 'sp. 2 ' is known from central Poland (Dollo, 1885a; Lingham-Soliar, 1992; Jagt et al., 2005).

Outside Europe, $H$. neumilleri may represent the genus in the Late Campanian of North America (but see Bullard \& Caldwell, 2010, for an opposing view). Lingham-Soliar (1994: 262, fig. $1 \mathrm{i}$ and $\mathrm{j}$ ) referred to at least two teeth from the Maastrichtian of Manzadi, Bas Congo, western Democratic Republic of Congo, as cf. Mosasaurus lemonnieri. They exhibit a strong labiolingual, subsymmetrical compression, shallow concave facets 
(c. six labially and 12-14 lingually) and well-developed mesial and distal carinae. These characters are congruent with those of the genus Hainosaurus and may indicate the presence of this genus in the Maastrichtian of central Africa.

\section{Comments on species previously referred to the genus Liodon Agassiz, 1846}

GZG.V.10024 was originally tentatively assigned to the problematic species 'Liodon' mosasauroides Gaudry, 1892 by Pompeckj (1910), although he referred the species to the genus Mosasaurus, following Dollo (1893). The main reason for this assignment was the labiolingually compressed, blade-like shape of the 'smooth' lateral teeth (Pompeckj, 1910: 126). While these similarities are only superficial (see above), the status of the genus Liodon has not yet been resolved satisfactorily. It was created as Leiodon by 0wen (1841, in Owen, 1840-1845) for its type species $L$. anceps, based on several teeth and associated jaw fragments from the Campanian of England. The genus name was preoccupied and substituted by the junior synonym Liodon Agassiz, 1846. While 0wen saw the most important difference in the smooth enamel in contrast to the faceted enamel of Mosasaurus, Dollo (1893) was the first to reject the validity of 'Leiodon', proposing synonymy with Mosasaurus. In the meantime a number of species have been referred to this genus, in part erroneously. Lingham-Soliar (1993) revised it and proposed four species to be valid, namely $L$. anceps, $L$. compressidens (Gaudry, 1892), L. sectorius Cope, 1871, and L. mosasauroides, forming a phylogenetic series of increasingly trenchant, smooth marginal teeth. However, doubts were expressed over the recognition of the type material of $L$. anceps, and recently Schulp et al. (2008) have proposed to transfer diagnosable species of the poorly known genus 'Liodon' to Prognathodon Dollo, 1889. Although this would appear an elegant approach in order to deal with the numerous problems surrounding the taxonomy of 'Liodon', caution is called for when considering that species with a strongly labiolingually compressed dentition should be indifferently included in the genus Prognathodon, which is generally characterised by conical, massive, more or less swollen or only slightly compressed, symmetrically cross-sectioned lateral teeth and procumbent premaxillary teeth in several species (see also Konishi et al., 2011).

'Liodon' sectorius, based on fragmentary remains from the Maastrichtian of New Jersey, USA, northeastern Belgium and possibly northern Spain (Cope, 1871; Russell, 1967; Kuypers et al., 1998; Bardet et al., 2012) shows dental characters that are clearly similar to those of Prognathodon spp., especially the swollen tooth bases and vestigial anastomosing wrinkles on otherwise smooth enamel. The labiolingually compressed, symmetrical cross-section of lateral tooth crowns is closely similar to that of P. kianda Schulp, Polcyn, Mateus, Jacobs \& Morais, 2008, from the Maastrichtian of Angola. However, it should be noted that $P$. kianda was found to be located outside of and more basal to a monophyletic genus Prognathodon in recent analyses (LeBlanc et al., 2012; Grigoriev, 2013). It may therefore form a sister-taxon to 'L.' sectorius in a still unnamed genus.

'Liodon' compressidens Gaudry, 1892 from the Early Campanian of France (Bardet, 2012) was assigned to 'Liodon' by Lingham-Soliar (1993) and to Prognathodon by Schulp et al. (2008) and Bardet (2012). However, the holotype and sole specimen known, MNHM AC 1878-575, is the rostral part of a skull which appears to show cranial and dental features that are more consistent with assignment to the Mosasaurini Gervais, 1853, than to Prognathodon. These include the narrow, tapering jaws, the presence of low and long maxillaries (which are generally shorter and taller in lateral aspect in Prognathodon spp., see, for example, Lingham-Soliar \& Nolf, 1990; Schulp, 2006: fig. 4; Konishi et al., 2011), and the presence of a small but distinct premaxillary rostrum, which is absent or very indistinct in most species of Prognathodon. Although Lingham-Soliar (1993) claimed that the degree of lateral compression shown in the cross-sections of the marginal teeth figured by Gaudry (1892: pl. I) was exaggerated, his own illustration (Lingham-Soliar, 1993: fig. 3) confirms the labiolingual compression and more importantly a slightly asymmetric crosssection of the bicarinate tooth crowns, with a more convex lingual face and weak faceting of both sides, lacking a swollen base. The overall cranial and dental morphology appears similar to that of the genus Clidastes Cope, 1868 (see Russell, 1967; Lindgren \& Siverson, 2004), although the size is much larger than is common in this genus, approaching the dimensions attained by Mosasaurus. Pending a revision of this material, inclusion of 'Liodon' compressidens into the Mosasaurini should be considered at least probable.

LeBlanc et al. (2012) also expressed doubt over the assignment of 'L.' mosasauroides to Prognathodon and proposed a closer relationship of the former with Mosasaurus. In our view this is also supported by the dental morphology of the holotype, which exhibits a marked asymmetry between a near-flat labial and a gently to rostrally increasingly convex lingual side (Gaudry, 1892: pl. II). At least the rostralmost dentary teeth have a distinct D-shaped cross-section, which is very similar to that in Mosasaurus spp. Although clearly highly derived, the dentition is still most close in morphology to and clearly derivative from that in Mosasaurus. The double row of vascular foramina on the maxillary and the presence of a small premaxillary rostrum also underscores a close relationship to the latter. 'Liodon' mosasauroides may therefore either be considered a highly derived species of Mosasaurus or belong to a still unnamed genus that probably evolved from the latter.

\section{Conclusions}

Two genera of tylosaurine mosasaurs, Tylosaurus and Hainosaurus, are recorded for the first time from the Campanian of 
Germany. Tylosaurus sp. is represented by two isolated tooth crowns, originally described as Mosasaurus? alseni (here considered a nomen dubium), which exhibit a close similarity to T. ivoensis and T. gaudryi.

The genus Hainosaurus is considered valid and distinct from Tylosaurus, despite minor osteological differences, for its significant modification in the dental apparatus in comparison to the plesiomorphic condition in the latter. The development of a cutting dentition from the generalised-piercing dentition of Tylosaurus was probably linked to major shifts in prey preference and feeding behaviour.

The material of Hainosaurus sp. from Germany comprises a maxillary with associated postorbitofrontal, two pterygoid teeth and several indeterminate cranial fragments. The specimen from the Late Campanian is slightly less derived than $H$. bernardi from the Early Maastrichtian in retaining less labiolingually compressed anterior maxillary teeth and unserrated pterygoid teeth with only very weak carinae. A short review indicates the presence of Hainosaurus in northern, central and western Europe (Sweden to Spain) ever since the Early Campanian, and the occurrence of Tylosaurus spp. in the same area up to the Late Campanian. Hainosaurus persisted until the end of the Maastrichtian and outside Europe it may have been present in the Late Campanian of the USA and the Maastrichtian of the Democratic Republic of Congo. The dental morphology of this genus shows some morphological modification throughout its existence, suggesting a phylogenetic trend in the marginal dentition of European tylosaurines from the robust, 'generalised' teeth of Tylosaurus gaudryi and T. ivoensis from the Campanian (Massare, 1987; Lindgren \& Siverson, 2002; Lindgren, 2005) towards the increasingly labiolingually compressed, symmetrical, strongly bicarinate, trenchant teeth of Hainosaurus sp. from the Early through Late Campanian and $H$. bernardi from the Early Maastrichtian (Dollo, 1885a,b; Lingham-Soliar, 1992; Lindgren, 2005). This morphocline may be extended into the Upper Maastrichtian with $H$. 'sp. 2' (sensu Jagt et al., 2005) from Poland, with marginal teeth that are strongly labiolingually compressed and have well developed denticles on the mesial and distal carinae. A similar trend is also present in the pterygoid teeth with very indistinct, unserrated carinae in the Campanian Hainosaurus sp. towards serrated carinae in the Maastrichtian $H$. bernardi.

Judging from a simple, uni- to bicarinate, stoutly conical tooth morphology in aigialosaurs and basal mosasaurs (Polcyn et al., 1999; Dutchak \& Caldwell, 2009), providing a grasping and piercing function, and phylogenetic patterns, the development of highly trenchant ('cut $\mathrm{II}^{\prime}$ ) dentitions seem to have been acquired convergently in several clades of large-bodied Campanian-Maastrichtian mosasaurids. These include mosasaurines ('L.' mosasauroides, Prognathodon? sectorius, Prognathodon? kianda, Eremiasaurus heterodontus LeBlanc, Caldwell \& Bardet, 2012) as well as tylosaurines (Hainosaurus spp.).

\section{Acknowledgements}

We thank John W.M. Jagt, Maastricht, and Anne S. Schulp, Leiden, for their thoughtful reviews of the manuscript. We are also indebted to Kyaw Winn and Eckart Bedbur (CAUK) for arranging the loan of the syntypes of Mosasaurus? alseni, and Sven Sachs (Engelskirchen) for support and discussions during the preparation of the manuscript.

\section{References}

Agassiz, L., 1846. Nomenclatoris zoologici index universalis, continens nomina systematica classium, ordinum, familiarum et generum animalium omnium, tam viventium quam fossilium, secundum ordinem alphabeticum unicum disposita, adjectis homonymiis plantarum, nec non variis adnotationibus et emendationibus. Jent et Gassmann (Solothurn): 1135 pp.

Bardet, N., 1990. Première mention du genre Hainosaurus (Squamata, Mosasauridae) en France. Comptes Rendus de l'Académie des Sciences (Série II: Mecanique-Physique, Chimie, Sciences de l'Univers, Sciences de la Terre) 311: 751-756.

Bardet, N., 2012. The Mosasaur collections of the Muséum National d'Histoire Naturelle of Paris. Bulletin de la Société Géologique de France 183(1): 35-53.

Bardet, N., Corral, J.C. \& Pereda Suberbiola, X., 1997. Les Mosasaures (Squamata) du Crétacé supérieur du Bassin basco-cantabrique. Geobios 30 (supplement 1) [20]: 19-26.

Bardet, N., Pereda Suberbiola, X. \& Corral, J.C., 2006. A Tylosaurine Mosasauridae (Squamata) from the Late Cretaceous of the Basque-Cantabrian Region. Estudios Geológicos 62(1): 213-218.

Bardet, N., Pereda Suberbiola, X., Corral, J.-C., Baceta, J.I., Torres, J.A., Botantz, B. \& Martin, G., 2012. A skull fragment of the mosasaurid Prognathodon cf. sectorius from the Late Cretaceous of Navarre (Basque-Cantabrian Region). Bulletin de la Société Géologique de France 183(2): 117-121.

Broom, $\boldsymbol{R} ., 1912$. On a Species of Tylosaurus from the Upper Cretaceous Beds of Pondoland. Annals of the South African Museum 7(1908-1913): 332-333.

Bullard, T.S. \& Caldwell, M.W., 2010. Redescription and rediagnosis of the tylosaurine mosasaur Hainosaurus pembinensis Nicholls, 1988, as Tylosaurus pembinensis (Nicholls, 1988). Journal of Vertebrate Paleontology 30(2): 416-426.

Caldwell, M.W. \& Diedrich, C., 2005. Remains of Clidastes Cope, 1868, an unexpected mosasaur in the upper Campanian of NW Germany. In: Schulp, A.S. \& Jagt, J.W.M. (eds): Proceedings of the First Mosasaur Meeting. Netherlands Journal of Geosciences/Geologie en Mijnbouw 84(3): 213-220.

Caldwell, M.W., Konishi, T., Obata, I. \& Muramoto, K., 2008. A new species of Taniwhasaurus (Mosasauridae, Tylosaurinae) from the upper Santonian-lower Campanian (Upper Cretaceous) of Hokkaido, Japan. Journal of Vertebrate Paleontology 28(2): 339-348.

Camp, C.L., 1923. Classification of the Lizards. Bulletin of the American Museum of Natural History 48(11): 289-481.

Cope, E.D., 1868. [Remarks on Clidastes iguanavus, Nectoportheus validus, and Elasmosaurus]. Proceedings of the Academy of Natural Sciences of Philadelphia 20: 181.

Cope, E.D., 1869. On the Reptilian Orders Pythonomorpha and Streptosauria. Proceedings of the Boston Society of Natural History 12: 250-266.

Cope, E.D., 1871. Supplement to the 'Synopsis of the Extinct Batrachia and Reptilia of North America'. Proceedings of the American Philosophical Society 12(86): 41-52. 
Diedrich, C. \& Mulder, E.W.A., 2004. A new record of Clidastes (Squamata, Mosasauridae) from the Upper Campanian of the Münster Basin (NW Germany). Netherlands Journal of Geosciences/Geologie en Mijnbouw 83(1): 73-78.

Dölling, M., Hiss, M. \& Kaplan, U., 2006. Haldem-Member. LithoLex (online database). Last updated 22/06/2006, record no. 2008038, BGR, Hannover. Available at http://www.bgr.bund.de/litholex.

Dölling, M., Hiss, M. \& Kaplan, U., 2010. Stemwede-Formation. LithoLex (online database). Last updated 16/03/2010, record no. 2008001, BGR, Hannover. Available at http://www.bgr.bund.de/litholex.

Dollo, L., 1882. Note sur l'ostéologie des Mosasauridae. Bulletin du Musée Royal d'Histoire naturelle de Belgique 1: 55-74.

Dollo, L., 1885a. Le Hainosaure. Revue des Questions Scientifiques 18: 285-289.

Dollo, $L ., 1885 \mathrm{~b}$. Première note sur le Hainosaure, mosasaurien nouveau de la craie brune phosphatée de Mesvin-Ciply, près Mons. Bulletin du Musée Royal d'Histoire naturelle de Belgique 4: 25-35.

Dollo, L., 1888. Sur le crâne des mosasauriens. Bulletin Biologique de la France et de la Belgique (3ème Série) 19(1): 1-11.

Dollo, $L$., 1889. Note sur les vertébrés récemment offerts au Musée de Bruxelles par M. Alfred Lemonnier. Bulletin de la Société Belge de Géologie, de Paléontologie et d'Hydrologie 3: 181-182.

Dollo, L., 1890. Première note sur les Mosasauriens de Maestricht. Bulletin de la Société Belge de Géologie, de Paléontologie et d'Hydrologie 4: 151-169.

Dollo, L., 1893. Suppression du genre Leiodon. Bulletin de la Société Belge de Géologie, de Paléontologie et d'Hydrologie 7: 79.

Dollo, L., 1904. Les mosasauriens de la Belgique. Bulletin de la Société Belge de Géologie, de Paléontologie et d'Hydrologie, Mémoires 18: 207-216.

Dutchak, A.R. \& Caldwell, M.W., 2009. A redescription of Aigialosaurus (= Opetiosaurus) bucchichi (Kornhuber, 1901) (Squamata: Aigialosauridae) with comments on mosasauroid systematics. Journal of Vertebrate Paleontology 29(2): 437-452.

Everhart, M.J., 2005. Tylosaurus kansasensis, a new species of tylosaurine (Squamata, Mosasauridae) from the Niobrara Chalk of western Kansas, USA. In: Schulp, A.S. \& Jagt, J.W.M. (eds): Proceedings of the First Mosasaur Meeting. Netherlands Journal of Geosciences/Geologie en Mijnbouw 84(3): 231-240.

Frenzel, P., Reich, M. \& Herrig, E., 2014. Ein Meer am Ende des Mesozoikums. Kreide. In: Rothe, P., Storch, V. \& See, C. von (eds): Lebensspuren im Stein: Ausflüge in die Erdgeschichte Mitteleuropas. Wiley-VCH Verlag (Weinheim): 166-176.

Gaudry, A., 1892. Les Pythonomorphes de France. Mémoires de la Société géologique de France (Paléontologie) 3(3)(10): 1-13.

Gervais, P., 1853. Observations relatives aux reptiles fossiles de France. Comptes Rendus hebdomadaires des Séances de l'Académie des Sciences 36: 374-377, 470-474.

Grigoriev, D.V., 2013. Redescription of Prognathodon lutugini (Squamata, Mosasauridae). Proceedings of the Zoological Institute of the Russian Academy of Sciences 317(3): 246-261.

Hornung, J.J. \& Reich, M., 2006. Mosasaurs of northern Germany (Late Cretaceous) - a preliminary account. Berichte des Instituts für Geowissenschaften, Christian-Albrechts-Universität Kiel 22: 39-40.

ICZN (International Commission on Zoological Nomenclature), 1999. International Code of Zoological Nomenclature, 4th edn. The International Trust for Zoological Nomenclature (London): $306 \mathrm{pp}$.

Jagt, J.W.M., 2005. Stratigraphic ranges of mosasaurs in Belgium and the Netherlands (Late Cretaceous) and cephalopod-based correlations with
North America. In: Schulp, A.S. \& Jagt, J.W.M. (eds): Proceedings of the First Mosasaur Meeting. Netherlands Journal of Geosciences/Geologie en Mijnbouw 84(3): 283-301.

Jagt, J.W.M., Lindgren, J., Machalski, M. \& Radwański, A., 2005. New records of the tylosaurine mosasaur Hainosaurus from the Campanian-Maastrichtian (Late Cretaceous) of central Poland. In: Schulp, A.S. \& Jagt, J.W.M. (eds): Proceedings of the First Mosasaur Meeting. Netherlands Journal of Geosciences/Geologie en Mijnbouw 84(3): 303-306.

Jagt, J.W.M., Motchurova-Dekova, N., Ivanov, P., Cappetta, H. \& Schulp, A.S., 2006. Latest Cretaceous mosasaurs and lamniform sharks from Labirinta cave, Vratsa district (northwest Bulgaria): a preliminary note. Geološki anali Balkanskoga poluostrva/Annales Géologiques de la Péninsule Balkanique 67: 51-63.

Jimenez-Huidobro, P. \& Caldwell, M.W., 2012. Hainosaurus versus Tylosaurus: is the former distinct from the latter? Journal of Vertebrate Paleontology 32 (Suppl 3): 118.

Klähn, H., 1929. Ein Gehäuse von Echinocorys (Ananchytes) ovatus Leske mit Kerben, ihre sedimentpetrogenetische Auswertung, speziell bezüglich der Feuersteinentstehung. Palaeobiologica 2: 251-263.

Knutsen, E.M., 2012. A taxonomic revision of the genus Pliosaurus (Owen, 1841a) Owen, 1841b. Norwegian Journal of Geology 92: 259-276.

Konishi, T., Brinkman, D., Massare, J.A. \& Caldwell, M.A., 2011. New exceptional specimens of Prognathodon overtoni (Squamata, Mosasauridae) from the upper Campanian of Alberta, Canada, and the systematics and ecology of the genus. Journal of Vertebrate Paleontology 31(5): 1026-1046.

Kuypers, M.M.M., Jagt, J.W.M., Peeters, H.H.G. \& de Graaf, D.T., 1998. Laat-kretaceische mosasauriers uit Luik-Limburg: nieuwe vondsten leiden tot nieuwe inzichten. Publicaties van het Natuurhistorisch Genootschap in Limburg XLI(1): 5-48.

Laurenti, J.N., 1768. Specimen medicum, exhibens synopsin reptilium emendatam cum experimentis circa venena et antidota reptilium austriacorum. Joan. Thom. Nob. de Trattnern (Viennae): $214 \mathrm{pp}$.

LeBlanc, A.R., Caldwell, M.W. \& Bardet, N., 2012. A new mosasaurine from the Maastrichtian (Upper Cretaceous) phosphates of Morocco and its implications for mosasaurine systematics. Journal of Vertebrate Paleontology 32(1): 82-104.

Lee, M.S.Y. \& Caldwell, M.W., 2000. Adriosaurus and the affinities of mosasaurs, dolichosaurs, and snakes. Journal of Paleontology 74(5): 915-937.

Lindgren, J., 2004. The utility of isolated teeth in mosasaur taxonomy. In: Schulp, A.S. \& Jagt, J.W.M. (eds): First Mosasaur Meeting, Abstract book and Field guide. Natuurhistorisch Museum Maastricht (Maastricht): 56 .

Lindgren, J., 2005. The first record of Hainosaurus (Reptilia: Mosasauridae) from Sweden. Journal of Paleontology 79(6): 1157-1165.

Lindgren, J. \& Siverson, M., 2002. Tylosaurus ivoensis: a giant mosasaur from the early Campanian of Sweden. Transactions of the Royal Society of Edinburgh: Earth Sciences 93(1): 73-93.

Lindgren, J. \& Siverson, M., 2004. The first record of the mosasaur Clidastes from Europe and its palaeogeographical implications. Acta Palaeontologica Polonica 49(2): 219-234.

Lingham-Soliar, T., 1992. The tylosaurine mosasaurs (Reptilia, Mosasauridae) from the Upper Cretaceous of Europe and Africa. Bulletin de l'Institut royal des Sciences naturelles de Belgique (Sciences de la Terre) 62: 171-194.

Lingham-Soliar, T., 1993. The mosasaur Leiodon bares its teeth. In: Sarjeant, W.A.(ed.): Fossil vertebrates: faunas and concepts. Modern Geology 18: 443-458.

Lingham-Soliar, T., 1994. First record of mosasaurs from the Maastrichtian (Upper Cretaceous) of Zaire. Paläontologische Zeitschrift 68(1-2): 259-265. 
Lingham-Soliar, T., 1995. Anatomy and functional morphology of the largest marine reptile known, Mosasaurus hoffmanni (Mosasauridae, Reptilia) from the Upper Cretaceous, Upper Maastrichtian of The Netherlands. Philosophical Transactions of the Royal Society of London (B: Biological Sciences) 347: 155-180.

Lingham-Soliar, T. \& Nolf, D., 1990. The mosasaur Prognathodon (Reptilia: Mosasauridae) from the Upper Cretaceous of Belgium. Bulletin de l'Institut Royal des Sciences Naturelles de Belgique (Sciences de la Terre) 9(for 1989): 137-190.

Machalski, M., Jagt, J.W.M., Dortangs, R.W., Mulder, E.W.A. \& Radwański, A., 2003. Campanian and Maastrichtian mosasaurid reptiles from central Poland. Acta Palaeontologica Polonica 48(3): 397-408.

Mantell, G., 1829. A tabular arrangement of the organic remains of the county of Sussex. Transactions of the Geological Society of London (2nd Series) 3(1): 201-216.

Marsh, 0.C., 1872. Note on Rhinosaurus. American Journal of Science (3rd series) 4(20): 147.

Martin, J.E., 2007. A North American Hainosaurus (Squamata: Mosasauridae) from the Late Cretaceous of southern South Dakota. In: Martin, J.E. \& Parris, D.C. (eds): The Geology and Paleontology of the Late Cretaceous Marine Deposits of the Dakotas. Geological Society of America, Special Paper 427: 199-207.

Massare, J.A., 1987. Tooth morphology and prey preference of Mesozoic marine reptiles. Journal of Vertebrate Paleontology 7(2): 121-137.

Mulder, E.W.A. \& Mai, H., 1999. The oldest tylosaurine mosasaur (Reptilia; Lacertilia) from the Late Cretaceous of Belgium: Hermann von Meyer (1860) revisited. Geologie en Mijnbouw 78(2): 207-213.

Mulder, E.W.A., Cornelissen, D. \& Verding, L., 2004. Is Mosasaurus lemonnieri a juvenile Mosasaurus hoffmanni? A discussion. In: Schulp, A.S. \& Jagt, J.W.M. (eds): First Mosasaur Meeting, Abstract book and Field guide, Natuurhistorisch Museum Maastricht (Maastricht): 62-66.

Niebuhr, B., 2010. Lägerdorf-Formation. LithoLex (online database). Last updated 12/03/2010, record no. 2008074, BGR, Hannover. Available at http://www.bgr.bund.de/litholex.

Nicholls, E.L., 1988. The first record of the mosasaur Hainosaurus (Reptilia: Lacertilia) from North America. Canadian Journal of Earth Sciences 25(10): 1564-1570.

Oppel, M., 1811. Die Ordnungen, Familien und Gattungen der Reptilien als Prodrom einer Naturgeschichte derselben. Joseph Lindauer (München): 86 pp.

Owen, $\boldsymbol{R}$., 1840-1845. Odontography; or, a treatise on the comparative anatomy of the teeth; their physiological relations, mode of development, and microscopic structure in the vertebrate animals. H. Bailliere (London). Vol. 1 (text): xix + lxxiv + 655 pp.; Vol. 2 (atlas): 37 pp.

Owen, $\boldsymbol{R} .$, 1850. Description of the Fossil Reptiles of the Chalk Formation. In: Dixon, F. (ed.): The Geology and Fossils of the Tertiary and Cretaceous Formations of Sussex. Longman, Brown, Green and Longman (London): 378-404.

Parkinson, J., 1822. Outlines of Oryctology. An Introduction to the Study of Fossil Organic Remains. Printed for the author (London): $346 \mathrm{pp}$.

Persson, P.O., 1963. Studies on Mesozoic marine reptile faunas with particular regard to the Plesiosauria. Publications from the Institutes of Mineralogy, Paleontology, and Quaternary Geology, University of Lund 118: 1-15.

Polcyn, M.J., Tchernov, E. \& Jacobs, L.L., 1999. The Cretaceous biogeography of the eastern Mediterranean with a description of a new basal mosasauroid from 'Ein Yabrud, Israel. In: Tomida, S., Rich, T.H. \& Vickers-Rich, P. (eds): Proceedings of the Second Gondwanan Dinosaur Symposium. National Science Museum Monographs [= Kokuritsu Kagaku Hakubutsukan] 15: 259-290.
Pompeckj, J.F., 1910. Über einen Fund von Mosasaurier-Resten im Ober-Senon von Haldem. Jahresberichte des Niedersächsischen geologischen Vereins zu Hannover 3: 122-140.

Reich, M. \& Frenzel, P., 2002. Die Fauna und Flora der Rügener Schreibkreide (Maastrichtium, 0stsee). Archiv für Geschiebekunde 3(2/4): 73-284.

Reich, M., Frenzel, P. \& Herrig, E., 2005. Ein Meer am Ende der Oberkreide. Die Schreibkreide. Biologie in unserer Zeit 35(4): 260-267.

Ross, M.R., 2009. Charting the Late Cretaceous seas: Mosasaur richness and morphological diversification. Journal of Vertebrate Paleontology 29(2): 409-416.

Russell, D.A., 1967. Systematics and morphology of American mosasaurs (Reptilia, Sauria). Peabody Museum of Natural History, Yale University, Bulletin 23: $1-241$.

Sachs, S., 2000. Mosasaurier-Reste aus der Oberkreide von Nordrhein-Westfalen. Geologie und Paläontologie in Westfalen 56: 35-44.

Sachs, S., 2006. First record of a mosasaur (Reptilia: Squamata) from the Upper Cretaceous of Central Germany. Abhandlungen und Berichte aus dem Museum Heineanum 7: 1-7.

Sachs, S., Hornung, J.J. \& Reich, M., 2014. Mosasaurs from Germany - a brief history of the first 100 years of research. Netherlands Journal of Geosciences/Geologie en Mijnbouw doi: 10.1017/njg.2014.16.

Schulp, A.S., 2006. A comparative description of Prognathodon saturator (Mosasauridae, Squamata), with note on its phylogeny. In: Schulp, A.S. (ed.): On Maastricht Mosasaurs. Publicaties van het Natuurhistorisch Genootschap in Limburg, XLV(1): 19-56.

Schulp, A.S., Polcyn, M.J., Mateus, O., Jacobs, L.L., Morais, M.L. \& da Silva Tavares, T., 2006. New mosasaur material from the Maastrichtian of Angola, with notes on the phylogeny, distribution and palaeoecology of the genus Prognathodon. In: Schulp, A.S. (ed.): On Maastricht Mosasaurs. Publicaties van het Natuurhistorisch Genootschap in Limburg, XLV(1): 57-67.

Schulp, A.S., Polcyn, M.J., Mateus, O., Jacobs, L.L. \& Morais, M.L., 2008. A new species of Prognathodon (Squamata, Mosasauridae) from the Maastrichtian of Angola, and the affinities of the mosasaur genus Liodon. In: Everhart, M.J. (ed.): Proceedings of the Second Mosasaur Meeting. Fort Hays Studies Special Issue 3: 1-12.

Stolley, E., 1892. Die Kreide Schleswig-Holsteins. Mittheilungen aus dem Mineralogischen Institut der Universität Kiel 1(4): 191-384 [also separately printed as PhD thesis, University of Munich: 119 pp, 1891].

Thevenin, A., 1896. Mosasauriens de la Craie Grise de Vaux-Éclusier prés Péronne (Somme). Bulletin de la Societé Géologique de France (3éme Série) 24(2): 900-916.

von Meyer, H., 1860. Saurier aus der Tuff-Kreide von Maestricht und Folx-les-Caves. Palaeontographica 7(4): 241-244.

Williston, S.W., 1895. New or little-known extinct vertebrates. Kansas University Quarterly3: 165-176.

Young, M.T. \& Andrade, M.B.de, 2009. What is Geosaurus? Redescription of Geosaurus giganteus (Thalattosuchia: Metriorhynchidae) from the Upper Jurassic of Bayern, Germany. Zoological Journal of the Linnean Society 157(2): 551-585.

Young, M.T., Brusatte, S.L., Andrade, M.B.de, Desojo, J.B., Beatty, B.L., Steel, L., Fernández, M.S., Sakamoto, M., Ruiz-Omeñaca, J.-L. \& Schoch, R.R., 2012. The cranial osteology and feeding ecology of the metriorhynchid crocodylomorph genera Dakosaurus and Plesiosuchus from the Late Jurassic of Europe. PLoS ONE 7(9): 1-42 [e44985]. 